بر آورد بيلان حجمى آب و الكوى رطوبتى آبيارى قطرهاى زيرسطحى در محيط متخلخل

افشين خورسند، محمد بزانه، سينا بشارت* و كامران زينالزاده'

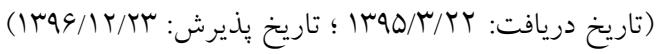

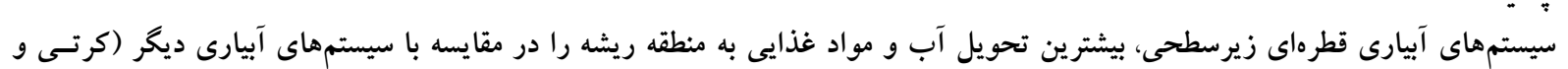

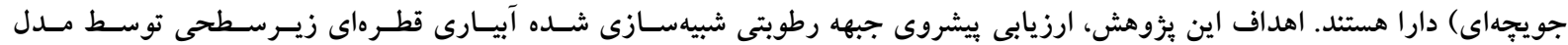

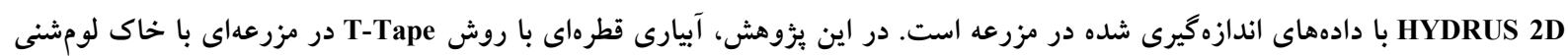

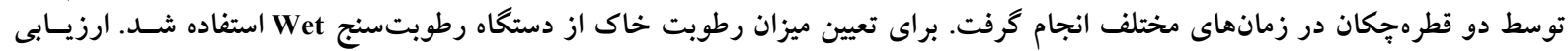

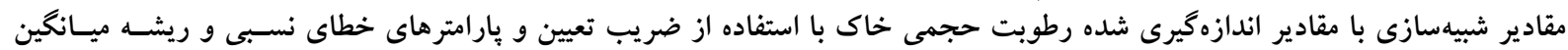

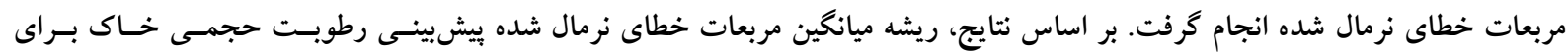

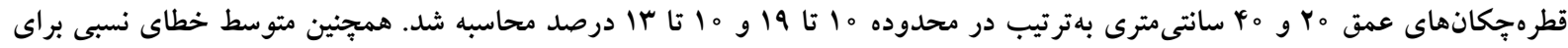

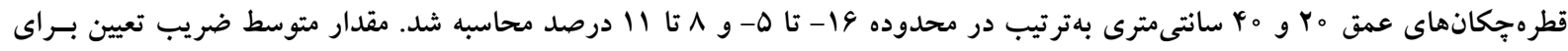

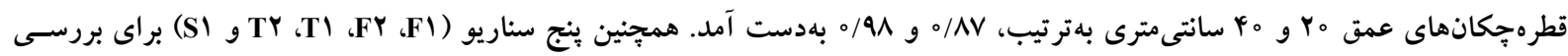

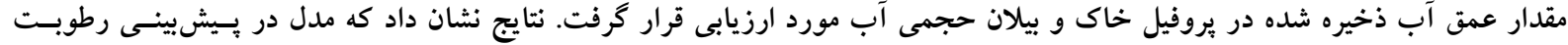

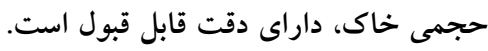

وازههاى كليدى: بيلان آب، سناريو، عمق آب ذخيره شده، مدل روزتا، مدل هايدروس

ا. كروه مهندسى آب، دانشكده كشاورزى، يُزوهشكده مطالعات درياجه اروميه، دانشكاه اروميه

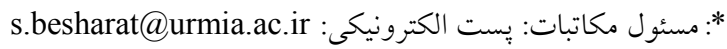




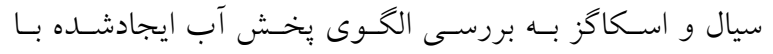

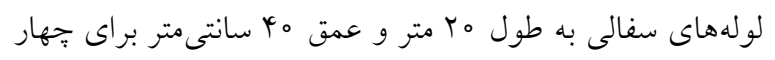

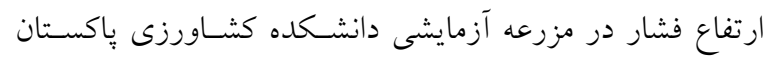

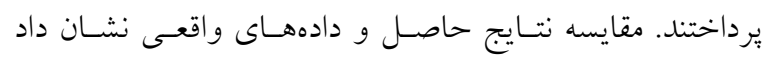

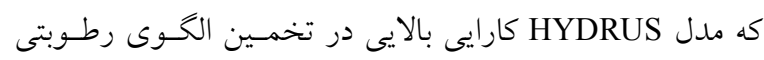

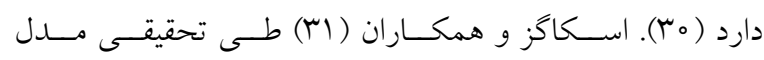
HYDRUS 2D

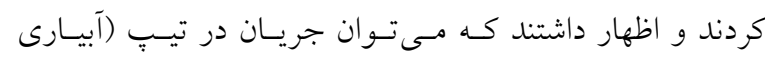
قطرهاى) را خطى در نظـر كرفـت و در دو بعـد بررسى كـرده،

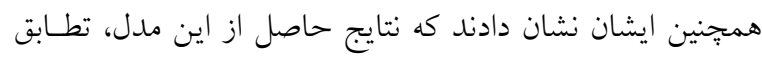

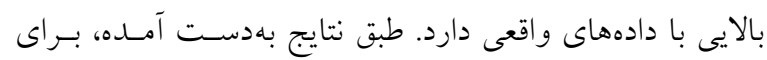

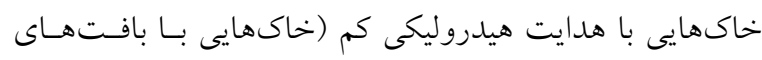

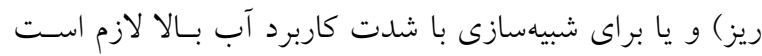

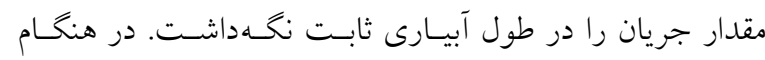

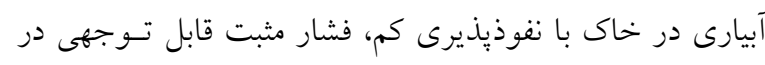

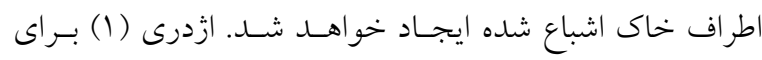
بررسى نحوه توزيع رطوبت بهصورت افقى و عمودى در ناحيه

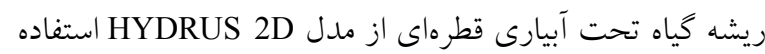

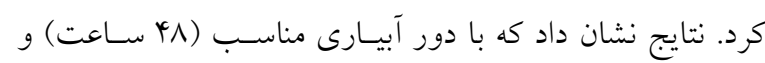

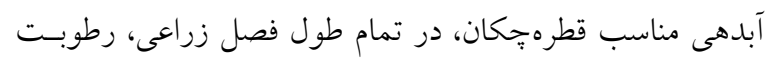

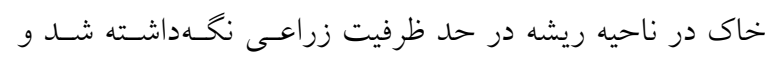

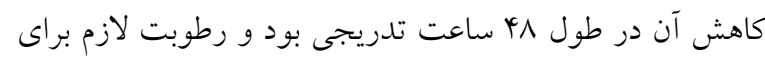

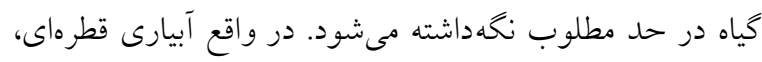

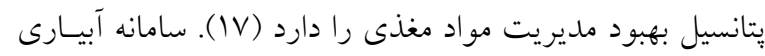

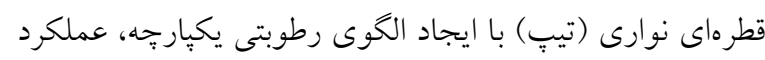
بهترى نسبت به قطرهجهانها دارد (Y) (Y).

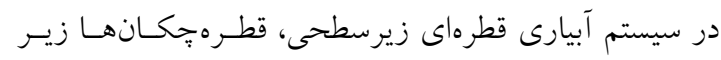

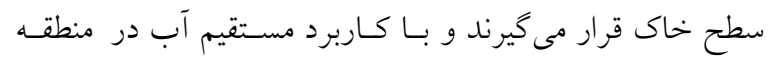

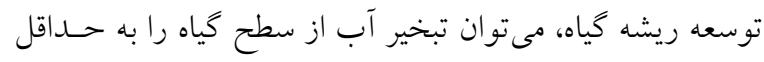

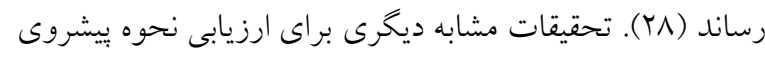

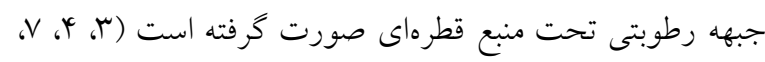

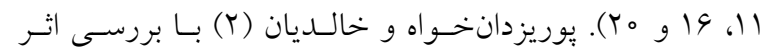

حركت آب در خاك عمدتاً بهوسيله جريان تودهاى ايجاد شـده

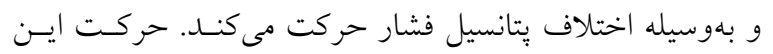

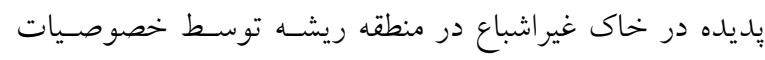

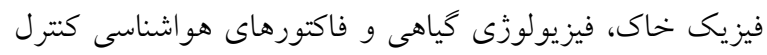

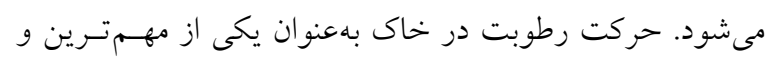

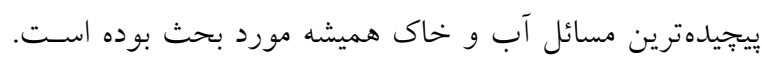

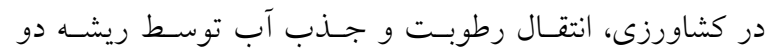

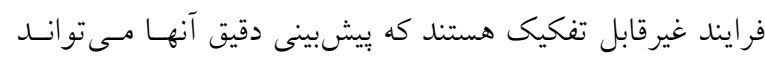

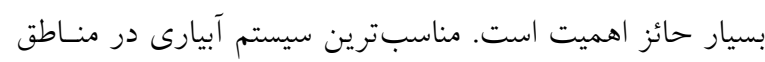

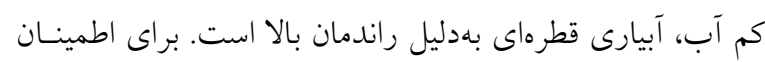

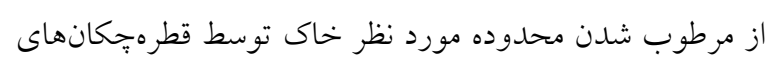

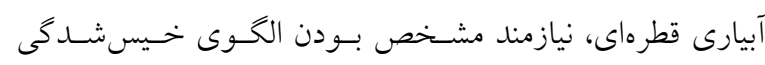

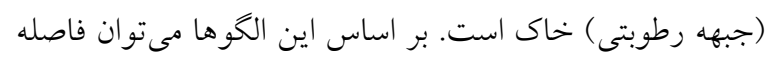
مناسب قطرهجكانها را تعيين كرد (r).

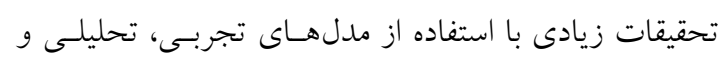

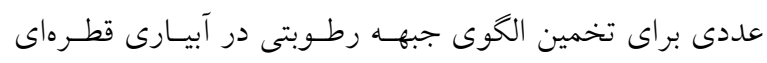

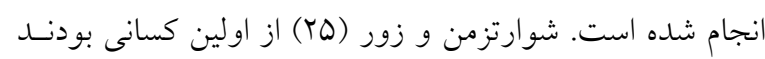

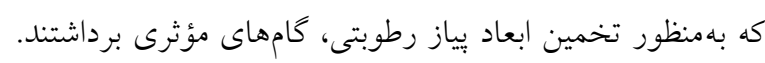

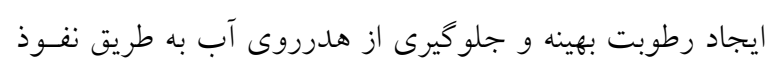

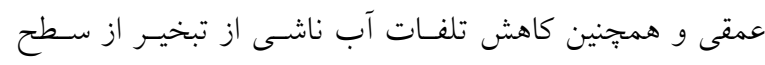

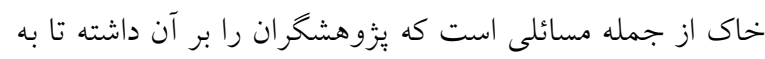

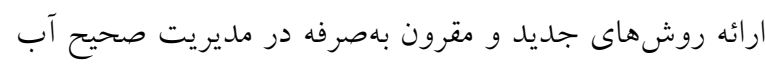

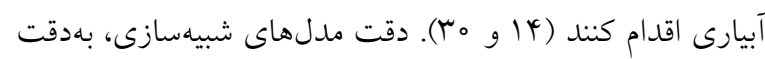

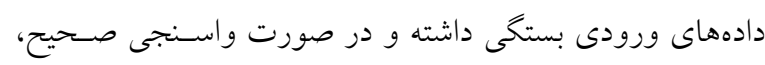

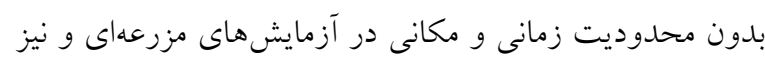

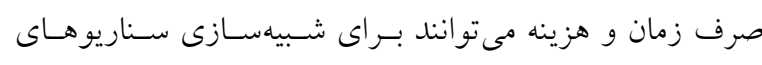

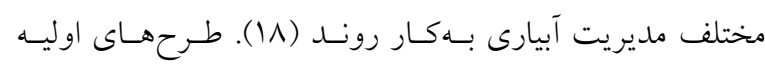

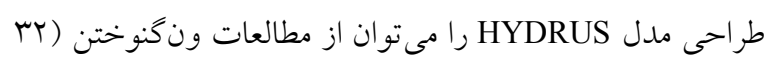

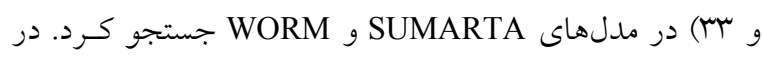

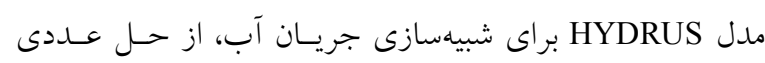
معادله ريجاردز استفاده مى ملود (YY). 
برآورد بيلان حجمى آب و الكوى رطوبتى آبيارى قطرهاى زيرسطحى در محيط متخلخل

جدول ا. مشخصات فيزيكى خاك مزرعه آزمايشى

\begin{tabular}{|c|c|c|c|c|c|c|c|}
\hline \multicolumn{2}{|c|}{ رطوبت خاى (\%) } & \multirow[b]{2}{*}{ 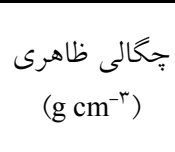 } & \multirow[b]{2}{*}{ 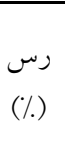 } & \multirow[b]{2}{*}{ سيلت } & \multirow[b]{2}{*}{ شن } & \multirow[b]{2}{*}{ بافت } & \multirow[b]{2}{*}{$\begin{array}{l}\text { عمق } \\
(\mathrm{cm})\end{array}$} \\
\hline $\begin{array}{c}\text { مكش 1000 } \\
(\mathrm{kPa})\end{array}$ & مكش سب & & & & & & \\
\hline$\Delta / 4$ & rA & $1 / 00$ & $0 / 9$ & $r q / 9$ & $\Delta \psi / \Lambda$ & لوم شنى & $\circ-100$ \\
\hline
\end{tabular}

يكنواختى بيشتر شخم زده شد. بافت خاك به روش هيدرومترى

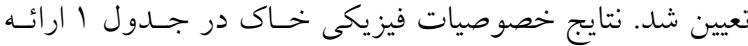
شده است. در ايسن تحقيـق از روش آبيـارى قطـــاى T-Tape ستفاده شد. قطر لو لهها دو سانتىمتر و فاصـله قطـرهجكـانهـا

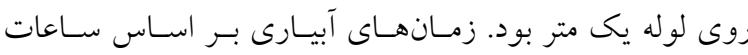

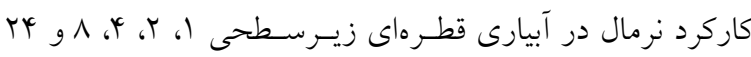

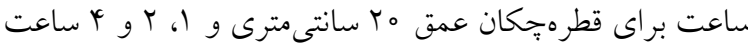

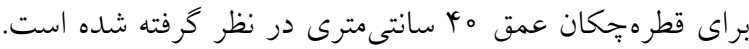
مقدار دبى قطرهجانها بر اساس اندازهيرى حجمى، جهار ليتر

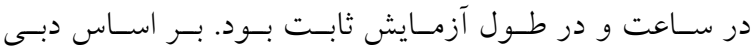
قطرهجكانها و زمان كاربرد، حجم آب كاربردى بهترتيب بـراى لون

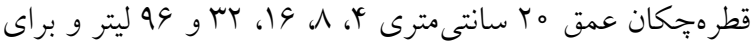

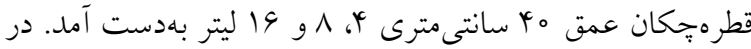

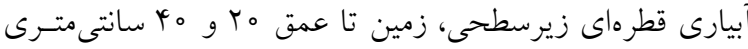

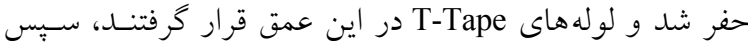
روى لوله ها خاك ريخته شد. براى تعيين ميزان رطوبت خـاك،

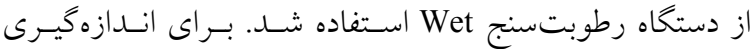
رطوبت خاك در نقاط مختلف، سنسورهاى دستكاه رطوبتسنج Wet در خاك منطقه مورد مطالعه قرار داده شد و رطوبتهـاى خاك در آن نقاط قرائت شد (شكل 1). سنسور Wet داراى سه شاخه است كه با قرار دادن آن در خاك مىتوان درصد رطوبت الترد

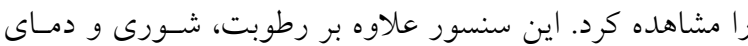
خاك را در نقطه مورد نظر اندازهگيرى مسى كنــ. ايسن داستشكاه

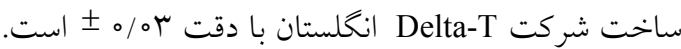

تشريح مدل HYDRUS 2D/3D با توجه به عدم هميوشـانى قطرهجـــانهـا (بـهدليـل فواصـل
اعمال تغييرات زمانى يارامترهاى هيدروليكى در شبيهسـازى بـاـ. مدل HYDRUS 2D به اين نتيجه رسيدند كه در شبيهسازى بـا اين مدل، لحاظ كردن تغييرات زمانى بــارامترهـاى هيــدروليكى خاك، نقش مهمى در بهبود نتايج شبيهسازى ايفا مى كند، بلويزه

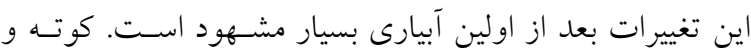

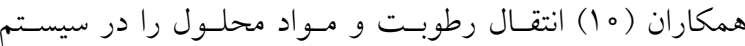
آبيارى قطرهاى زيرسطحى مـورد بررسـى قــرار دادنــــــ و اظهـار

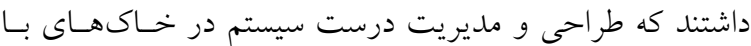
نفوذيذيرى كم و بافت ريز، مىتواند خصوصسيات هيـدروليكى

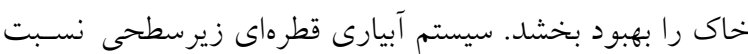
به ديخر روشهاى آبيارى، بهعلت كفايت آب كـاربردى بيشـتر، يشرفت قابل ملاحظهاى داشته است. در تحقيقـات محسـدودى ارزيـابى بيــاز رطـوبتى آبيـارى

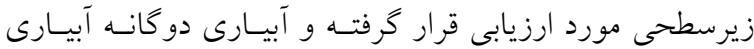

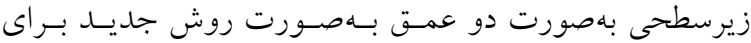
مصرف، تاكنون مورد بحث قرار كرفته نشده است. اهداف ايسن

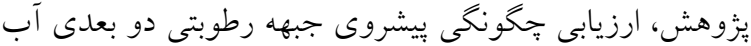
و مقايسه دادههاى مزرعهاى با دادههاى شبيهسازى شـــه آبيـارى

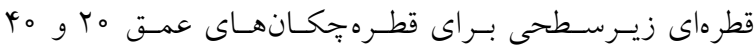
سانتى مترى و برآورد بيلان حجمى آب است.

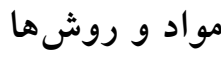 آزمايش هاى ميدانى} آزمايشهاى ميدانى روى خاكى بــا بافت لـوم شـنى در مزرعـهـ

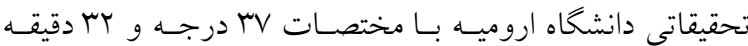

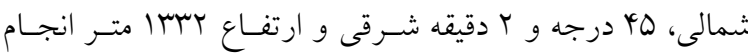

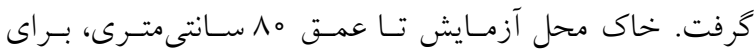


نشريه علوم آب و خاك (علوم و فنون كثاورزى و منابع طبيعى) / سال بيست و دو / شماره جهارم / زمستان ITVV

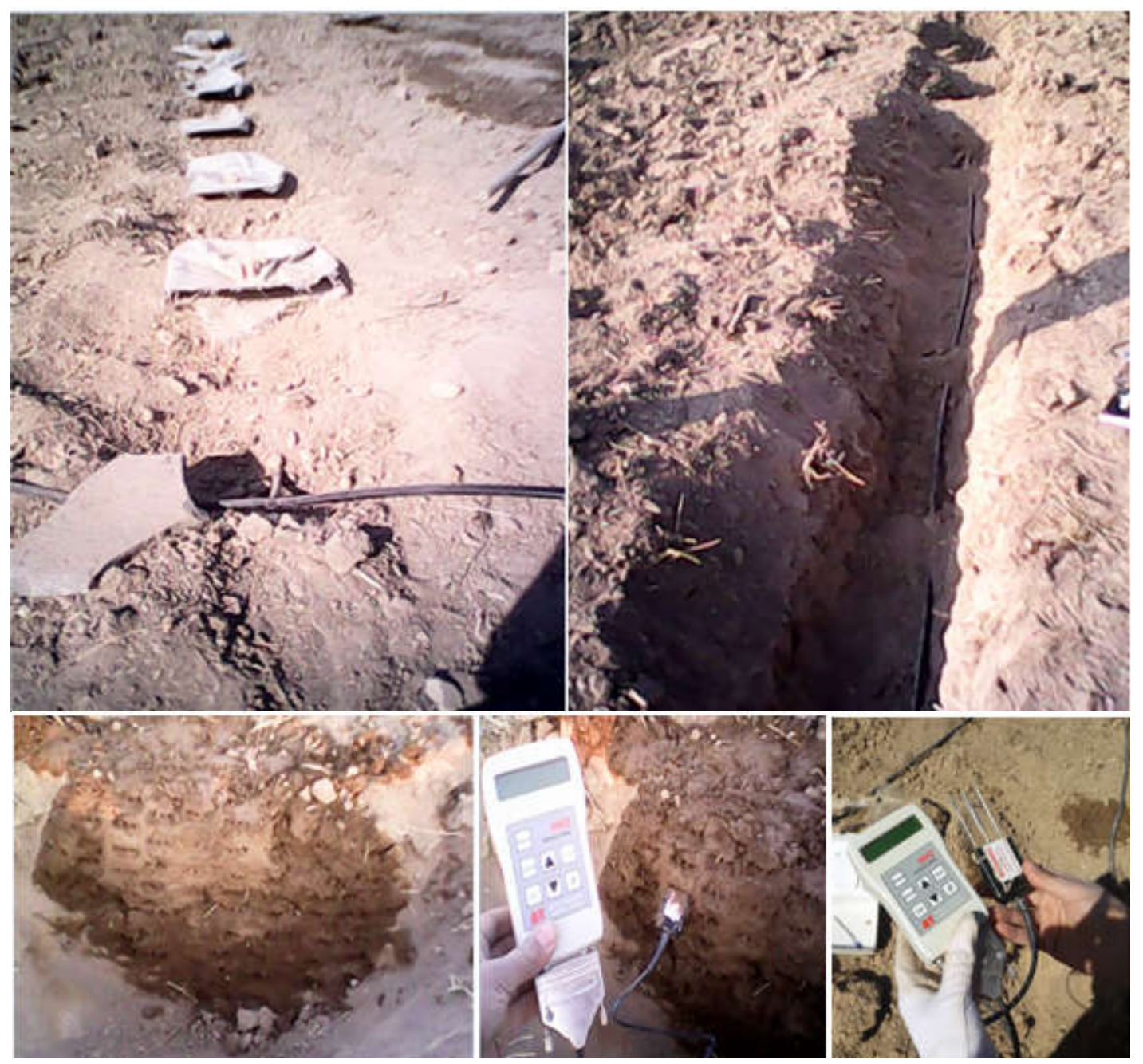

شكل ا. يروفيل رطوبتى خاك براى آبيارى قطرهاى زيرسطحى، محل قطرهجكانها و دستگاه رطوبتسنج

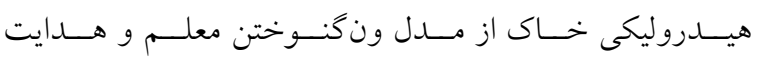

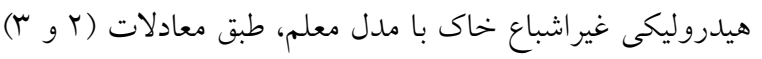
بهدست مى آيد:

$\left.\theta(\mathrm{h})=\theta_{\mathrm{r}}+\frac{\theta_{\mathrm{s}}-\theta_{\mathrm{r}}}{\left(1+|\alpha \mathrm{h}|^{\mathrm{n}}\right)^{\mathrm{m}}}, \mathrm{m}=1-\frac{1}{\mathrm{n}}, \mathrm{n}\right\rangle$

$\mathrm{K}(\mathrm{h})=\mathrm{K}_{\mathrm{s}}\left(\frac{\theta-\theta_{\mathrm{r}}}{\theta_{\mathrm{s}}-\theta_{\mathrm{r}}}\right)^{\prime}\left[1-\left(1-\left(\frac{\theta-\theta_{\mathrm{r}}}{\theta_{\mathrm{s}}-\theta_{\mathrm{r}}}\right)^{\frac{1}{\mathrm{~m}}}\right)^{\mathrm{m}}\right]^{\mathrm{r}}$

$(r)$

كه در آن؛ حجمى باقيمانده در خاك (

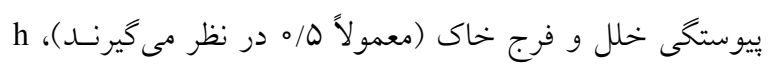

قطرهجكانها و تأثير بافت خاك)، روند حركت آب در طول نفوذ

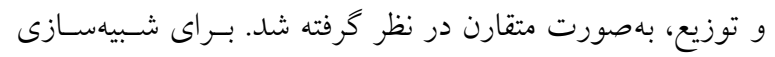

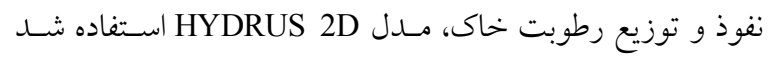

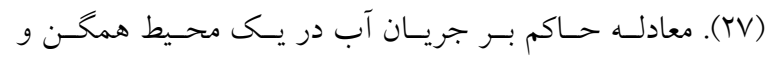

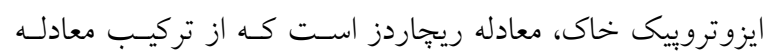
دارسى و قانون بقاى جرم بهدست آمده و بهصورت زير است: $\frac{\partial \theta}{\partial \mathrm{t}}=\frac{1}{\mathrm{r}} \frac{\partial}{\partial \mathrm{r}}\left[\mathrm{rK}(\mathrm{h}) \frac{\partial \mathrm{h}}{\partial \mathrm{r}}\right]+\frac{\partial}{\partial \mathrm{z}}\left[\mathrm{K}(\mathrm{h}) \frac{\partial \mathrm{h}}{\partial \mathrm{z}}+\mathrm{K}(\mathrm{h})\right]$ كه در آن؛ $\theta$ رطوبت حجمى آب خاك، h بّنانسيل فشارى آب،

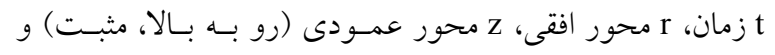

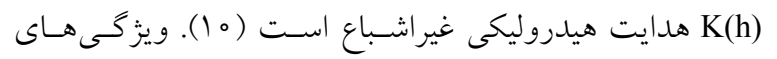


برآورد بيلان حجمى آب و الكوى رطوبتى آبيارى قطرهاى زيرسطحى در محيط متخلخل

جدول r. تخمين پِارامترهاى هيدروليكى خاك توسط مدل Rosetta

\begin{tabular}{|c|c|c|c|c|c|c|c|c|c|}
\hline \multicolumn{9}{|c|}{ يار امترهاى هيدروليكى خاى } & \multirow{2}{*}{$\begin{array}{c}\text { عمق (cm) } \\
0-100 \\
0\end{array}$} \\
\hline$\theta_{\mathrm{s}}$ & $\left(\frac{\mathrm{cm}^{r}}{\mathrm{~cm}^{-r}}\right)$ & $\theta_{\mathrm{r}}$ & $\left(\frac{\mathrm{cm}^{r}}{\mathrm{~cm}^{-r}}\right)$ & $\mathrm{K}_{\mathrm{s}}\left(\frac{\mathrm{cm}}{\mathrm{day}}\right)$ & $\mathrm{n}(-)$ & & $\left(\frac{1}{\mathrm{~cm}}\right)$ & $1(-)$ & \\
\hline & ०/TYV & & $0 / 0 q^{\prime}$ & $1 \mathrm{~W} / \mathrm{VG}$ & $1 / 199$ & & $1 O O T \Delta$ & $\circ / 0$ & \\
\hline
\end{tabular}

كار مدل Rosetta استفاده از روشهاى بهينهسازى شبكه عصبى

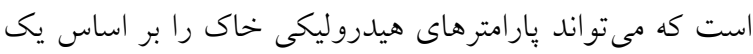
سرى از اطلاعـات ورودى تخمـين بزنســ. در مــدل Rosetta از خصوصيات ساده (زوديافت مانند درصد شن، سـيلت و رس)،

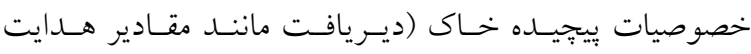
هيدروليكى و منحنى مشخصه رطوبتى خاك) برآورد مىشـوند.

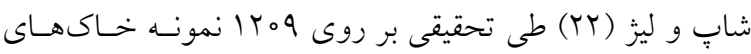
دنيا، سعى كردند با استفاده از مــدلهـاى مبتنى بـر شـبكههـاى عصبى، يُار امترهاى مدل منحنى مشخصه رطوبتى ون گنـوختن را حدس بزنند. در اين مدل، ينج سطح داده مورد نياز استفاده شده و هر سطح نسبت به سطح قبلى، نيازمند تعـداد ورودى بيشـترى

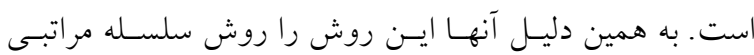

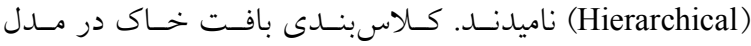
Rosetta هيدروليكى خاك بوده و داراى دقت بايينى است. بيبحيدهترين روش بر اساس درصد شـن، سـيلت و رس، جخــالى ظـاهرى،

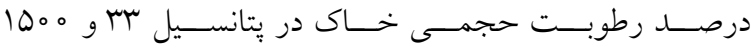

كيلو ياسكال است (جدول Y) (YV).

\section{سناريوهاى مورد مطالعه}

در اين تحقيق، ينج سناريو توسط مدل HYDRUS 2D تعريــف شد تا تأثير اين سناريوها روى بيشروى جبهه رطوبتى و مقـدار آب ذخيره شده در يروفيل خاى ارزيابى شود. ايسن سـناريوهـا

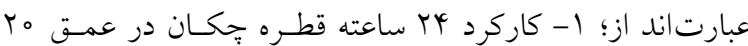

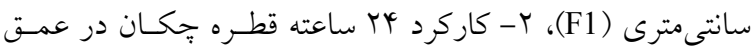
r。 ro
مكش ماتريك (L)، n و m يارامترهاى شكل منحنسى مشخصـه رطوبتى خاى، م عكس مقدار ورود هوا ( هيدروليكى اشباع خاى ( از روش عناصر محدود خطى نوع گالركين براى حل معـادلات

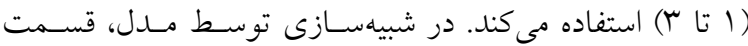
راست بياز رطوبتى در نظر گرفته شد. مشبندى مرزها در روش عناصر محدود مسـتطيلى و در لبـههـاى جبهـه رطـوبتى خـاك بهصورت مثلثى در نظر كرفته شد. در طول كاربرد آب در مرز، شدت جريان ثابت س/// سانتىمتر بر ساعت براى لوله مـورد

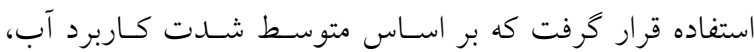
جهار ليتر بر ساعت در واحد متر در نظر گرفته شد.

شرايط اوليه و مرزى

رطوبت اندازهگيرى شده خاك قبل از انجام آزمايش، بـهـعـوان شرايط اوليه در نظر كرفته شد و ايسن مقـدار در تمـام يروفيـل خاى داراى مقدارى ثابت بـود. يـس از اتمـام آبيـارى، شـرايط مرزى لوله قطرهج جان بهصورت شرايط مرزى با جريان صفر و سطح خاى بهعنوان شرايط مرزى بالادست در نظر كرفتـه شـد كه برابر مقدار تبخير از سطح خاى اسـت. زهكشىى آزاد بـراى حركت آب در مرز پاييندست در نظر كرفته شد.

مدل Rosetta اجراى مدل HYDRUS-2D به بِارامترهـاى هيـدروليكى خـاك

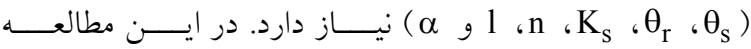
يارامترهـاى هيــرووليكى خــاك توسـط مــدل Rosetta كــه در HYDRUS-2D 

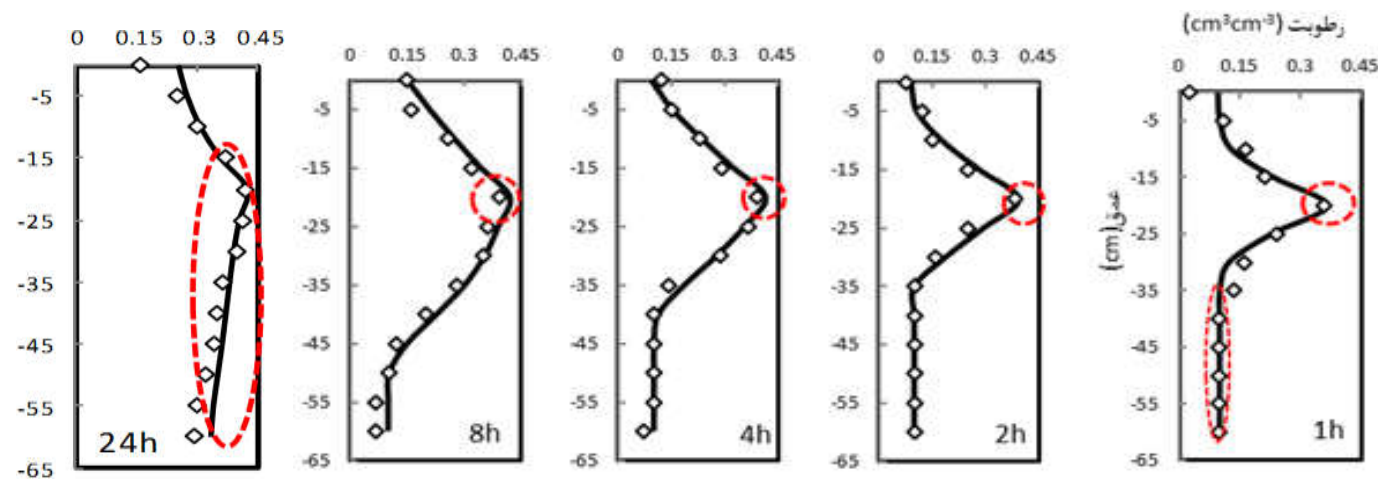

شكل r. مقايسه رطوبتهاى اندازهيرى شده (نقاط خالى) و شبيهسازى شده (خط ممتد) توسط مدل HYDRUS-2D

كه در آن: Si مقادير بيشبينىشده، Oi مقادير اندازهيرى شـده،

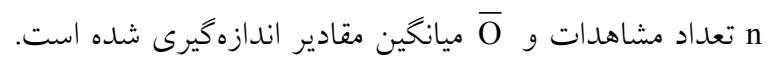

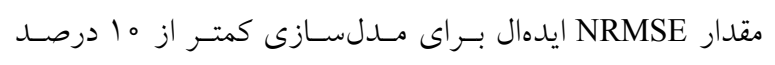

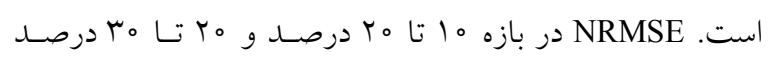

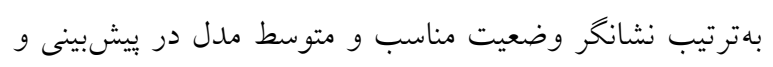

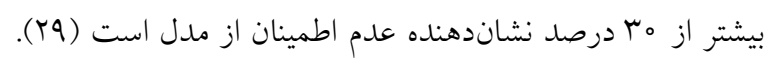

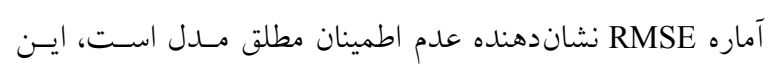

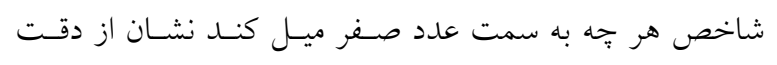

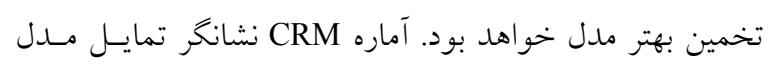

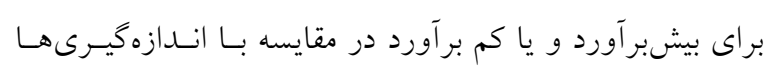

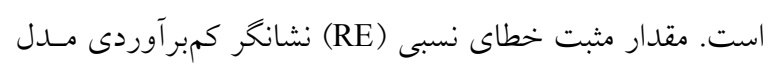

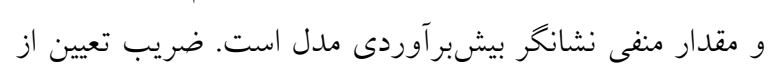
صفر تا يك متغير است (9).

\section{نتايج و بحث \\ شبيه سازى رطوبت حجمى}

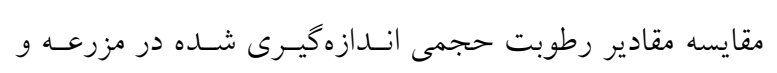

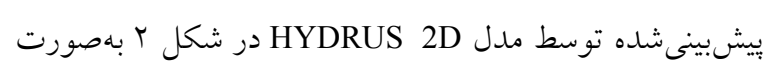

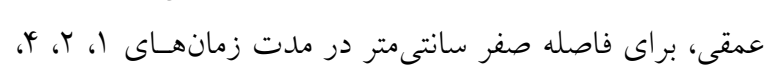

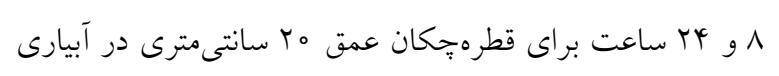

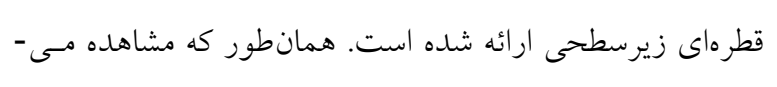

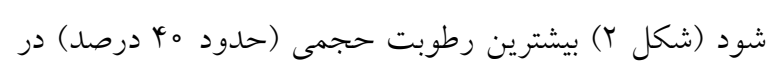

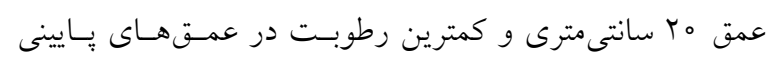

سانتىمترى در r ا ساعت اول و كاركرد قطـرهجكـان عمـق

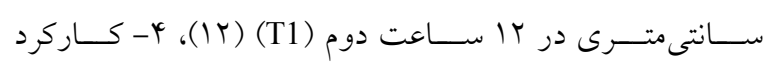

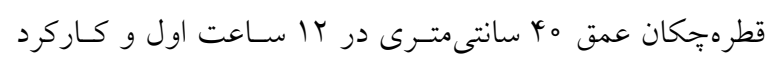

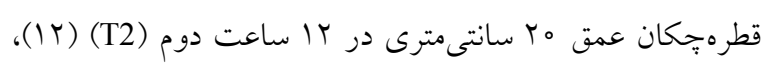

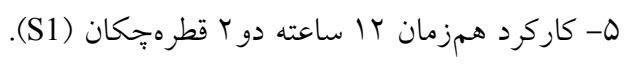

HYDRUS 2D ارزيابى مدل براى ارزيابى و سنجش اعتبار مدل با نتايج اندازهيرى در سـطح

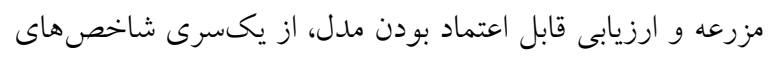

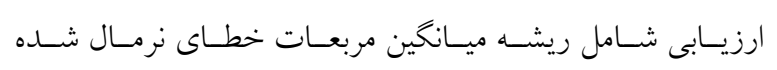

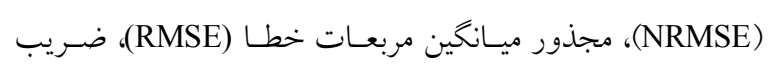

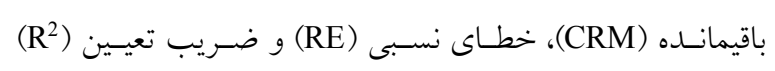

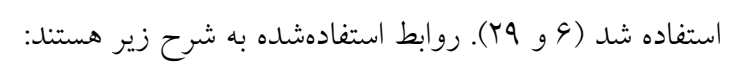
NRMSE $=\frac{\text { RMSE }}{\overline{\mathrm{O}}} 1$ 。

RMSE $=\sqrt{\frac{1}{n} \sum_{i=1}^{n}\left(S_{i}-O_{i}\right)^{r}}$

$\mathrm{CRM}=1-\left(\sum_{\mathrm{i}=1}^{\mathrm{n}} \mathrm{S}_{\mathrm{i}} / \sum_{\mathrm{i}=1}^{\mathrm{n}} \mathrm{O}_{\mathrm{i}}\right)$

$\mathrm{RE}=\sum_{\mathrm{i}=1}^{\mathrm{n}}\left(\frac{\mathrm{O}_{\mathrm{i}}-\mathrm{S}_{\mathrm{i}}}{\mathrm{O}_{\mathrm{i}}}\right) \times 10$

$R^{r}=\left[\frac{\sum_{i=1}^{n}\left(\mathrm{O}_{i}-\overline{\mathrm{O}}\right)\left(\mathrm{S}_{\mathrm{i}}-\overline{\mathrm{S}}\right)}{\sqrt{\sum_{\mathrm{i}=1}^{\mathrm{n}}\left(\mathrm{O}_{\mathrm{i}}-\overline{\mathrm{O}}\right)^{r} \sum_{\mathrm{i}=1}^{\mathrm{n}}\left(\mathrm{S}_{\mathrm{i}}-\overline{\mathrm{S}}\right)^{r}}}\right]^{r}$ 
برآورد بيلان حجمى آب و الكوى رطوبتى آبيارى قطراى زيرسطحى در محيط متخلخل

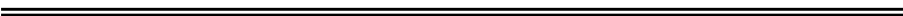

جدول r. بارامترهاى آمارى ارزيابى مدل براى قطرهجكان عمق ب سانتىمترى

\begin{tabular}{|c|c|c|c|c|c|}
\hline $\begin{array}{c}\text { NRMSE } \\
(\%)\end{array}$ & $\begin{array}{c}\text { RMSE } \\
\left(\mathrm{cm}^{3} \mathrm{~cm}^{-3}\right)\end{array}$ & $\begin{array}{c}\mathrm{CRM} \\
(-)\end{array}$ & $\begin{array}{l}\mathrm{RE}^{*} \\
(\%)\end{array}$ & $\begin{array}{l}\mathrm{R}^{2} \\
(-)\end{array}$ & زمان (ساعت) \\
\hline $1 N / 4 T_{q}$ & $\%$ \% TV & $0 / 019$ & $-10 / 00 \wedge$ & $\circ / \wedge \Delta Q$ & 1 \\
\hline Ir/rar & ०/० Y० & $-0 / 0 \mathrm{VW}$ & $-9 / 099$ & $0 / 9 \mathrm{VV}$ & r \\
\hline$\| / T I V$ & O/OYI & $-0 / 0 r q$ & $-Q / V A \mid$ & $0 / 999$ & 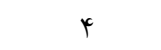 \\
\hline$|r / 4 T|$ & \% TV & $-0 / 1 \circ V$ & -19/N49 & $\circ / 9 V r$ & $\wedge$ \\
\hline $10 / 0 T q$ & - & $-0 / 090$ & $-9 / T G 4$ & -/QVQ & YY \\
\hline IT/MAT & $0 / 0 Y 4$ & $-0 / 0 \Delta F$ & $-10 / 9 \mathrm{VA}$ & $0 / 199$ & متوسط \\
\hline
\end{tabular}

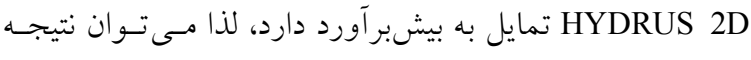
كرفت كه اين مدل در اين زمانها رطوبـت را بيشـتر از مقــادير

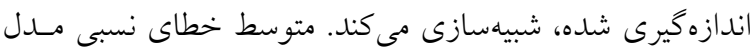

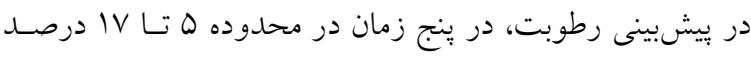

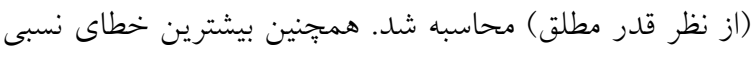

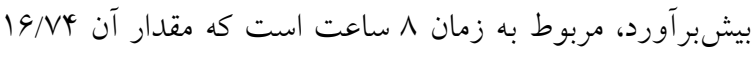
درصد (از نظر قدر مطلق) محاسبه شـــ نمايسه ضـريب تعيسين

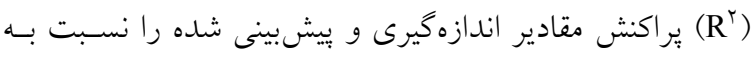

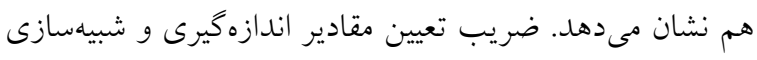

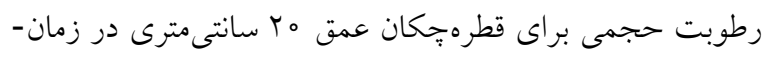

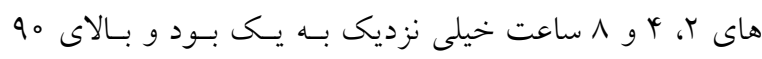

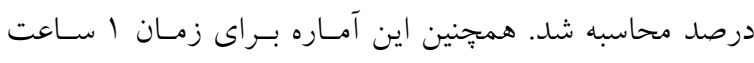

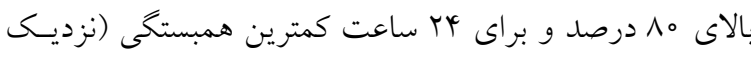

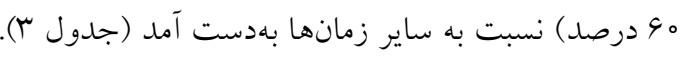

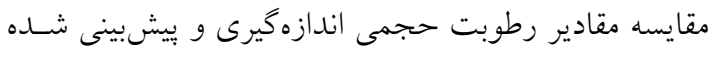

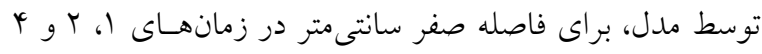

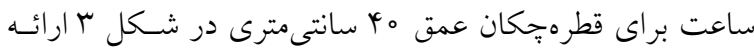

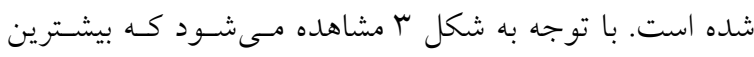

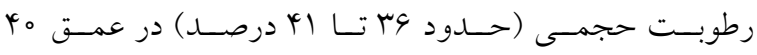

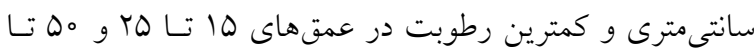

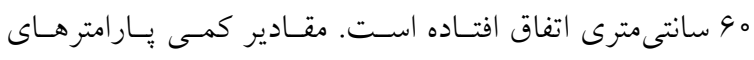

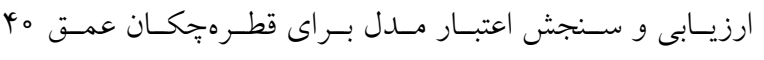

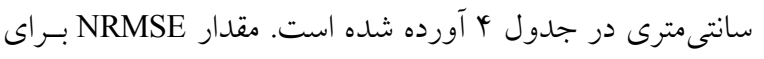

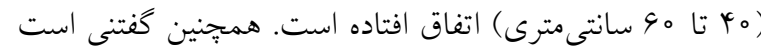

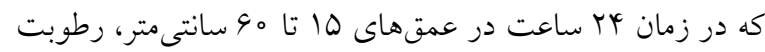

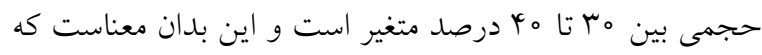

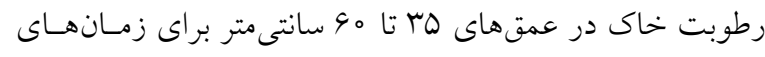

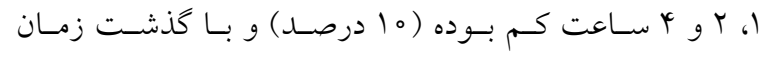

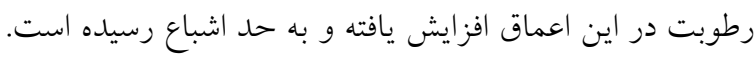

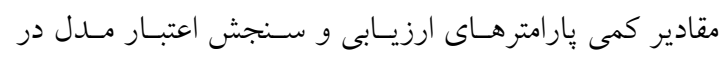

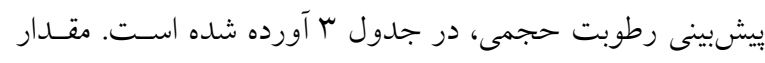

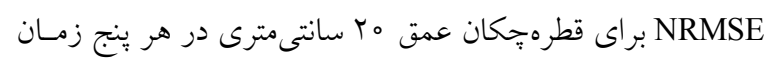

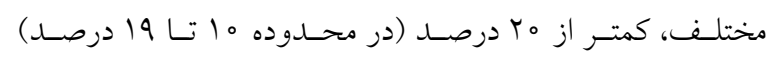

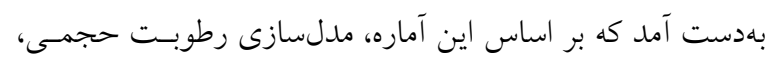

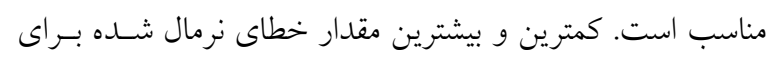

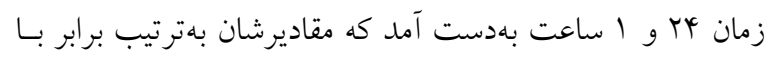

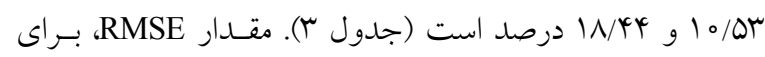

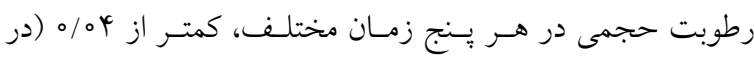

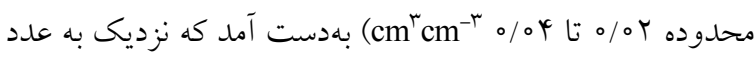

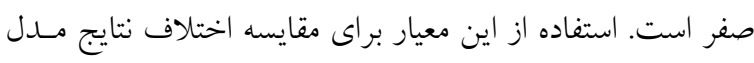

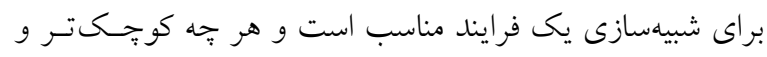

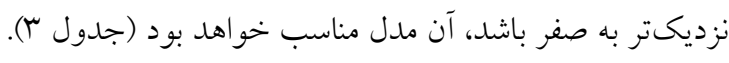

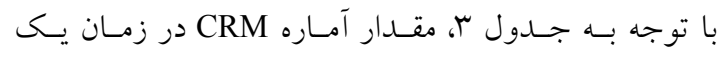

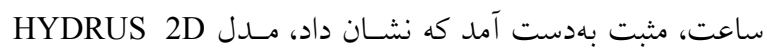

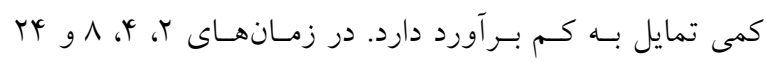

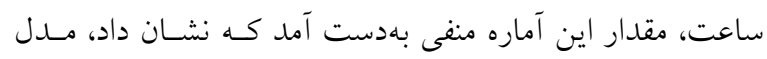




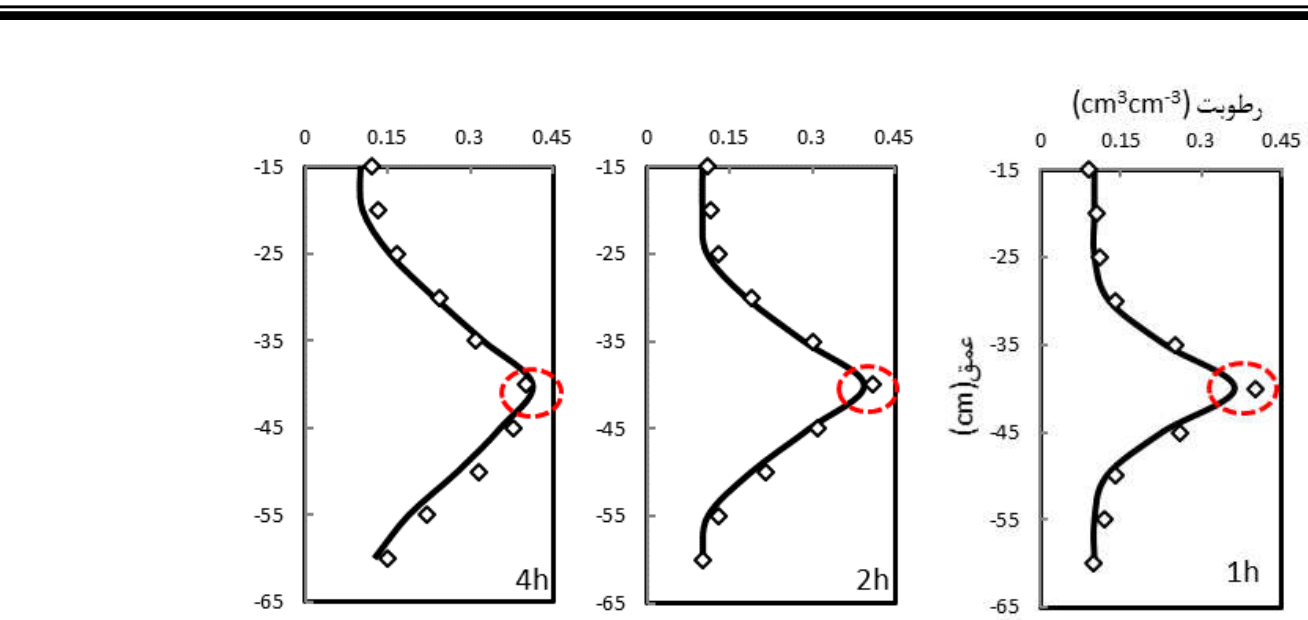

شكل r. مقايسه رطوبتهاى اندازهيرى شده (نقاط خالى) و شبيهسازى شده (خط ممتد) توسط مدل HYDRUS-2D

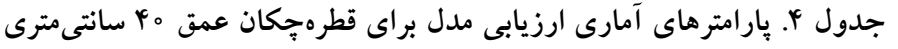

\begin{tabular}{|c|c|c|c|c|c|}
\hline $\begin{array}{c}\text { NRMSE } \\
(\%)\end{array}$ & $\begin{array}{c}\text { RMSE } \\
\left(\mathrm{cm}^{3} \mathrm{~cm}^{-3}\right)\end{array}$ & $\begin{array}{c}\text { CRM } \\
(-)\end{array}$ & $\begin{array}{l}\mathrm{RE}^{*} \\
(\%)\end{array}$ & $\begin{array}{l}\begin{array}{l}\mathrm{R}^{2} \\
(-)\end{array} \\
\end{array}$ & زمان (ساعت) \\
\hline$I T / T \Delta \Delta$ & O/OYI & $0 / 094$ & N/TYV & $0 / 91 \mathrm{~V}$ & 1 \\
\hline $10 / 091$ & O/OYY & $0 / 091$ & 10/Rry &.$/ 91 r$ & r \\
\hline$q / \Delta \wedge \psi^{r}$ & سYוץ & $0 / 091$ & $9 / Y 94$ & $0 / 999$ & $r$ \\
\hline $10 / N \mid r$ & O/OYY & o/oNk & $Q / T \wedge F$ &.$/ 9 V \wedge$ & متوسط \\
\hline
\end{tabular}

* مقادير مثبت، كمبرآورد و مقادير منفى، بيشبر آورد هستند.

زمان مختلف مربوط به زمـان دو سـاعت اسـت. ضـريب تعيسين مقادير اندازهيرى و شبيهسازى رطوبت حجمى براى قطرهجـان

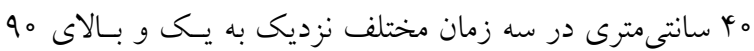
درصد محاسبه شد (جدول ث). سيال و اسكاگز (ب) براى شبيهسازى رطوبت حجمى خاى در بافتهاى مختلـف (شـنى، لـوم شـنى، لـومى و سـيلتى) در

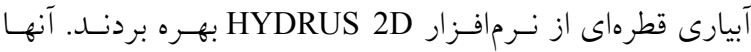
نتيجه كرفتند كه بيشبينسى درصــ رطوبـت حجمسى خـاك بـا استفاده از اين مدل همبستكى خوبى با دادههاى مشاهداتى دارد (ضريب تعيين 91/ بهدست آمد). در تحقيـق حاضـر ضـريب تعيين رطوبت حجمى براى قطرهج

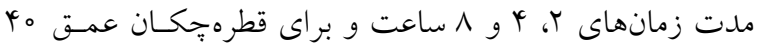

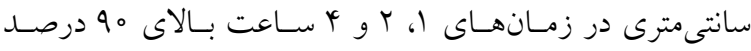
محاسبه شد كه با نتايج سيال و اسكاگز تطابق مناسـبى دارد. در
زمانهاى † ساعت كمتر از ما درصد (9/0/ درصد) بهدست آمد

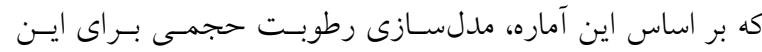
زمان، ايدهال است. مقدار NRMSE براى زمانهاى ا و r ساعت كمتر از مب درصد (در محدوده ها تا با درصد) بهدست آمد كه بر اساس اين آماره، مدلسازى رطوبـت حجمسى، مناسـب اسـت (جدول \&). مقدار RMSE، براى رطوبت حجمى در هر سه زمان مختلف كمتر از ro/\% (در محسدوده ro/ ) بهدست آمد كه نزديك به عدد صفر اسـت. مثبـت بـودن مقـادير نشان مىدهد كه در مجموع مدل HYDRUS 2DM رطوبت

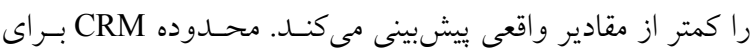

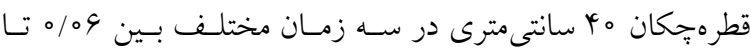

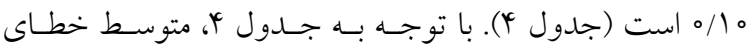
نسبى مدل در بيشيبنى رطوبت حجمى، در ا، r و أ سـاعت در محدوده ^ تا لا درصد محاسبه شد كه بيشترين خطا در بين سـه 
نتايج شان و همكـاران (Y9)، كانــلوس و سـيمونك (1) (1)،

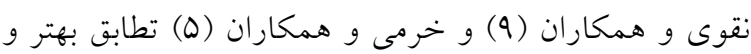

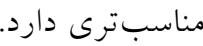

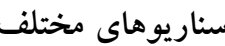

در شكل با توزيع رطوبت حجمى در فواصل عمـودى ه، مال،

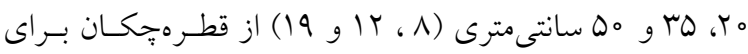

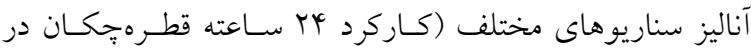

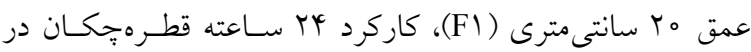

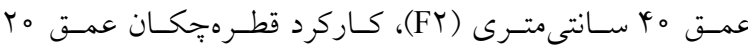

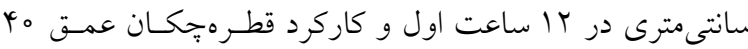
سانتى مترى در r| ساعت دوم (T)، كاركرد قطرهجكـان عمـق

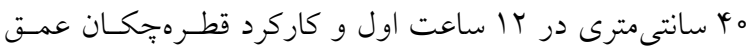

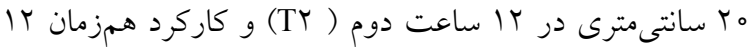

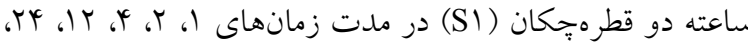

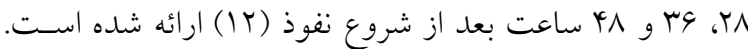

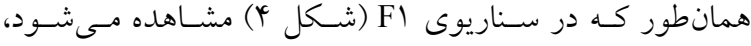

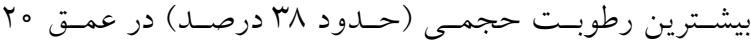

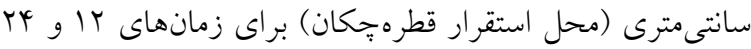
سـاعت در فواصـل ه و ه ا سـانتىمتـرى عمـودى و كمتـرين

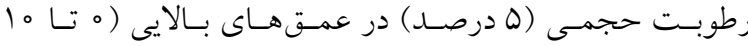

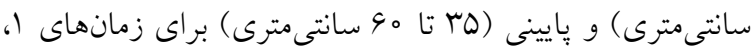

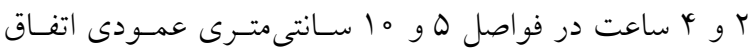
افتاده است. قابل ذكر است كه در زمانهـاى ل، ب و ب ســاعت،

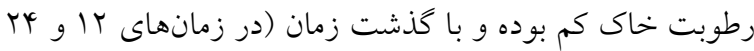

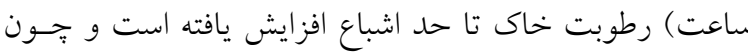

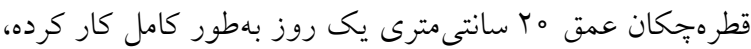

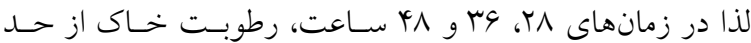

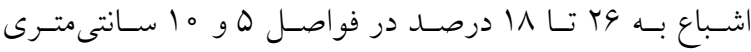

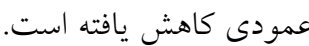

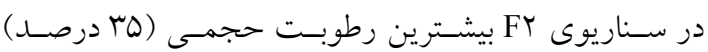

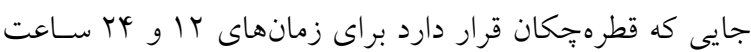

تحقيقى با استفاده از نرمافزار HYDRUS حركت آب در اطـراف

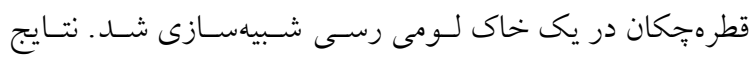

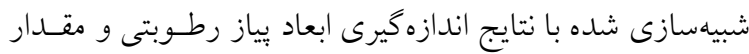

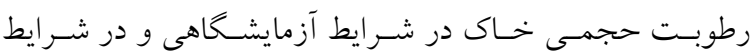

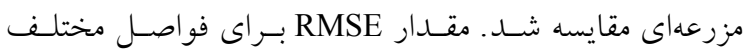

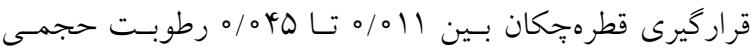

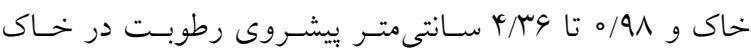

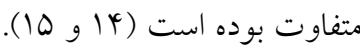

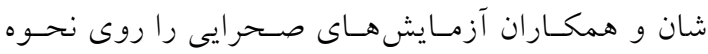
توزيع رطوبت حجمى در آبيارى قطرهاى انجام داده، سبس به به رانه

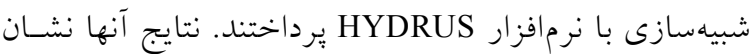

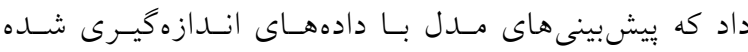

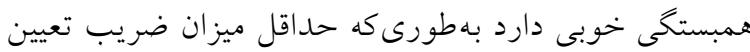

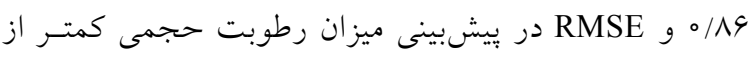

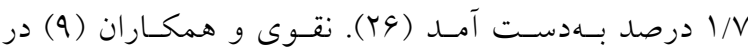
تحقيقى به بررسى بيشبينى توزيع رطوبت در خاك اطراف

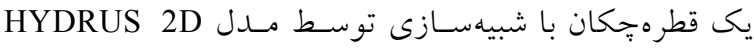
يرداختند. حداكثر ميزان خطاى RMSE، هه / بهدسـت آمـــ

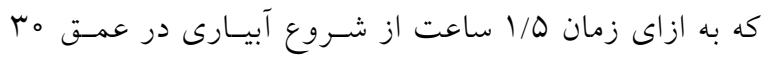

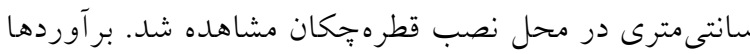

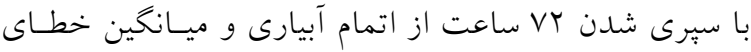

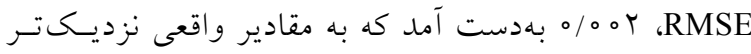

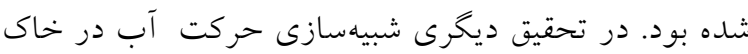

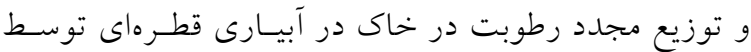
مدل HYDRUS 2D انجام گرفت. براساس نتسايج بسهدست متست آمده ميزان RMSE در درصد رطوبت حجمسى خـاك بـراى

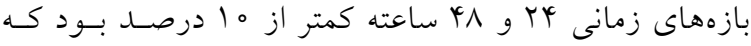
نشان از قدرت بالاى مدل در شبيهسازى دارد. بيشترين ميزان حداكثر خطا ينج درصد حجمى رطوبت و ميانخين مطلق خطا

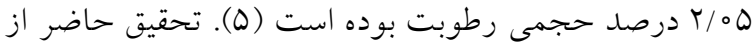
نظر ضريب تعيين و RMSE رطوبست حجمس خـاك بـراى

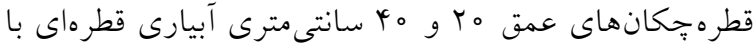




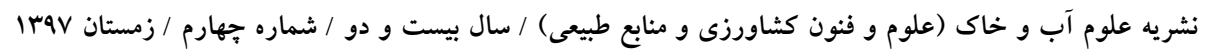

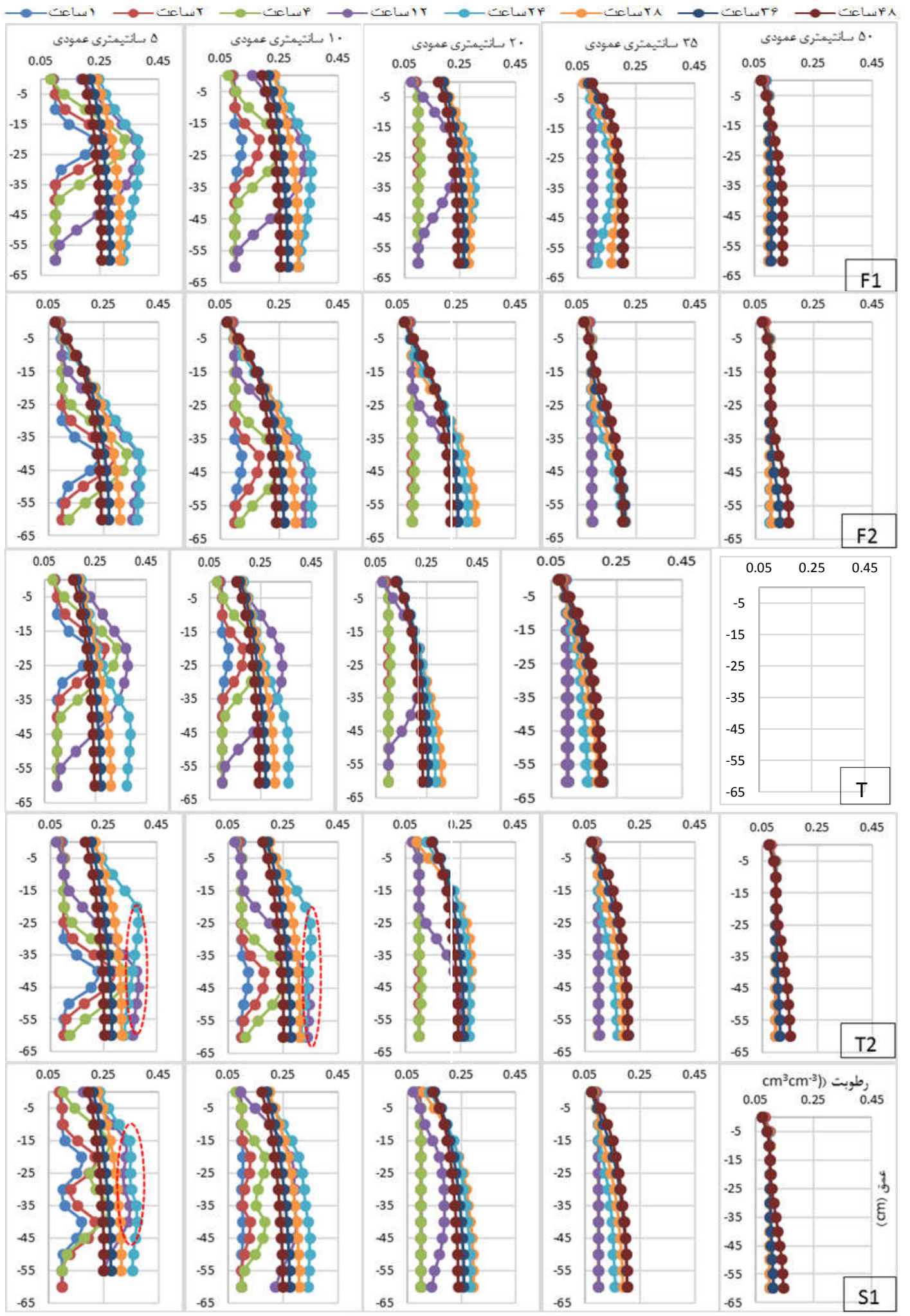

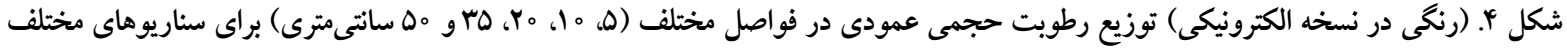


شكل مشخصشده است). درنهايت در سناريوى آخــر (SI) دو

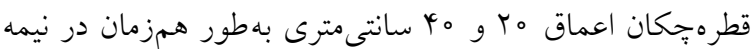
ول روز (rا ساعت اول) كار مى كنند. در فاصله ه سانتىمترى

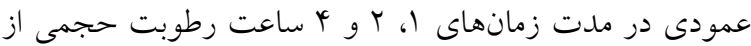

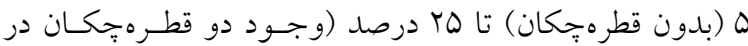

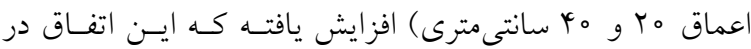

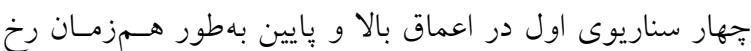

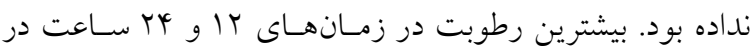

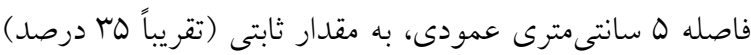

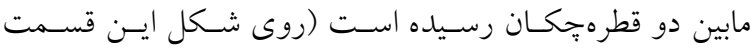

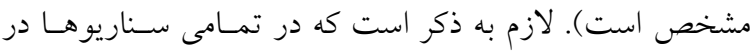

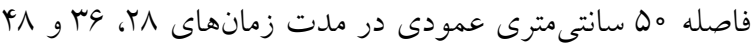

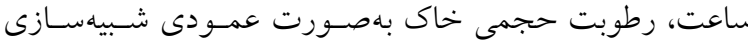
شده و رطوبت از ها (اعماق بالا) تا ها درصد (اعماق بـايين) متغير بوده است. - ماست

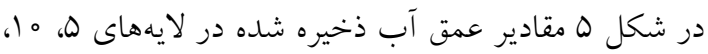

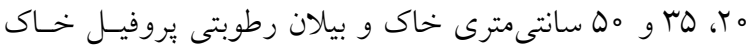
در زمانهاى مختلف براى بنج سناريو تعريف شده توسط مــدل را نشان مى دهد. همانطور كه در شكل ه مشـاهده

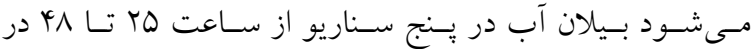
لايههاى مختلف خاى داراى مقدار منفى است و تخليـه آب در

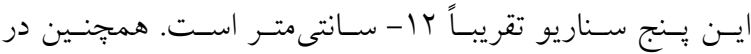

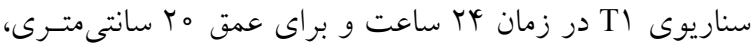

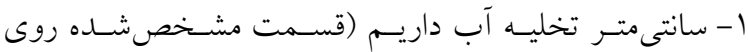
شكل). بيلان آب در ع r ساعت اول داراى مقدار مثبتى (تخليـه

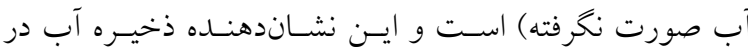
لايههاى مختلف خاك طى مدت زمـان ب Tـ سـاعت اول اسـت. بيشترين عمق آب ذخيره شده در عمق هله سـانتىمترى بـراى

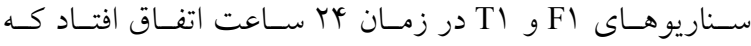

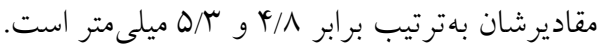
همجنين در سناريوى T2 بيشترين عمق آب ذخيره شده بـهـ

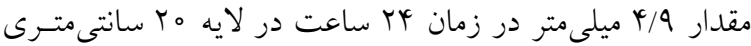

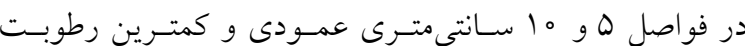
حجمى (ه درصد) در عمقهاى بالايى (ه تا •ب سانتىمترى) و

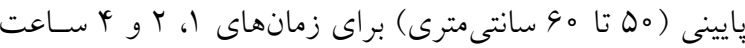
در فواصل هـ و ه إنتى مترى عمودى رخ داده است. هم:جنين در زمانهاى ل، ب و ^ ساعت رطوبـت خـاك كمتـر بـود و در زمانهاى Yl و و M ساعت رطوبت تا حلد اشباع افزايش يافتـه و

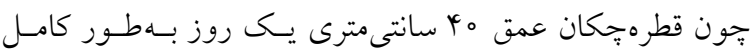

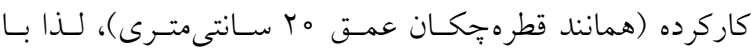

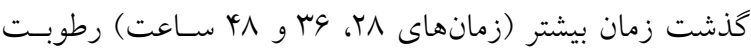

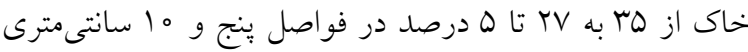

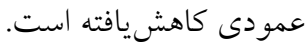

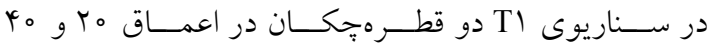
سانتى مترى بهترتيب در نيمه اول روز (Yl ساعت اول) و نيمـهـ

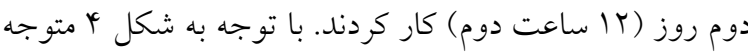
خو اهيم شد كه در فواصل ه و ه إنتى مترى عمودى، بيشترين رطوبت حجمى در جاهايى كه قطرهجكانها قرار دارند بهدست

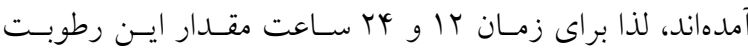

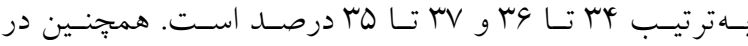
سناريوى Tr همانند سناريوى TT دو قطرهجاء ان وجود دارد بـا اين تفاوت كه در نيمه اول روز قطرهجهان عمق ه ب سانتىمترى

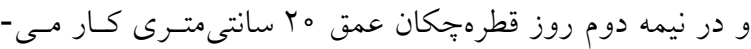

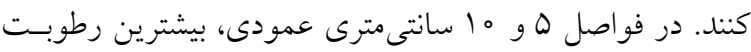
حجمى براى زمان Y ا و Y M ساعت بهدست آمد. كفتنى است كه

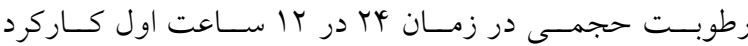

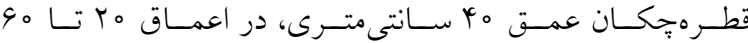
سانتى متـرى يروفيـل خـاك كـاهش جشـمخيرى نداشـت، لـــا

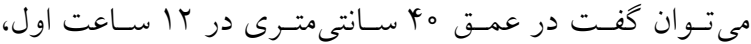
رطوبت خاك به حد اشباع رسيد و زمانى كه رطوبـت حجمسى

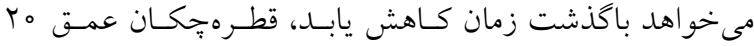
سانتى مترى در r| ساعت دوم شروع به كار مسىكنــ و جلـوى كاهش رطوبت حجمى اعماق بايين بروفيل خاك كرفتهشـده و رطوبت حجمى به مقدار ثابتى مىرسد (در سـناريوى Tr روى 


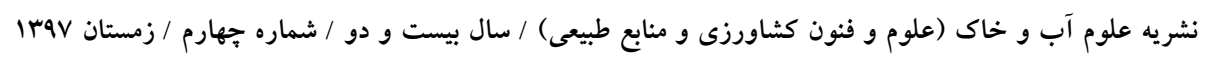
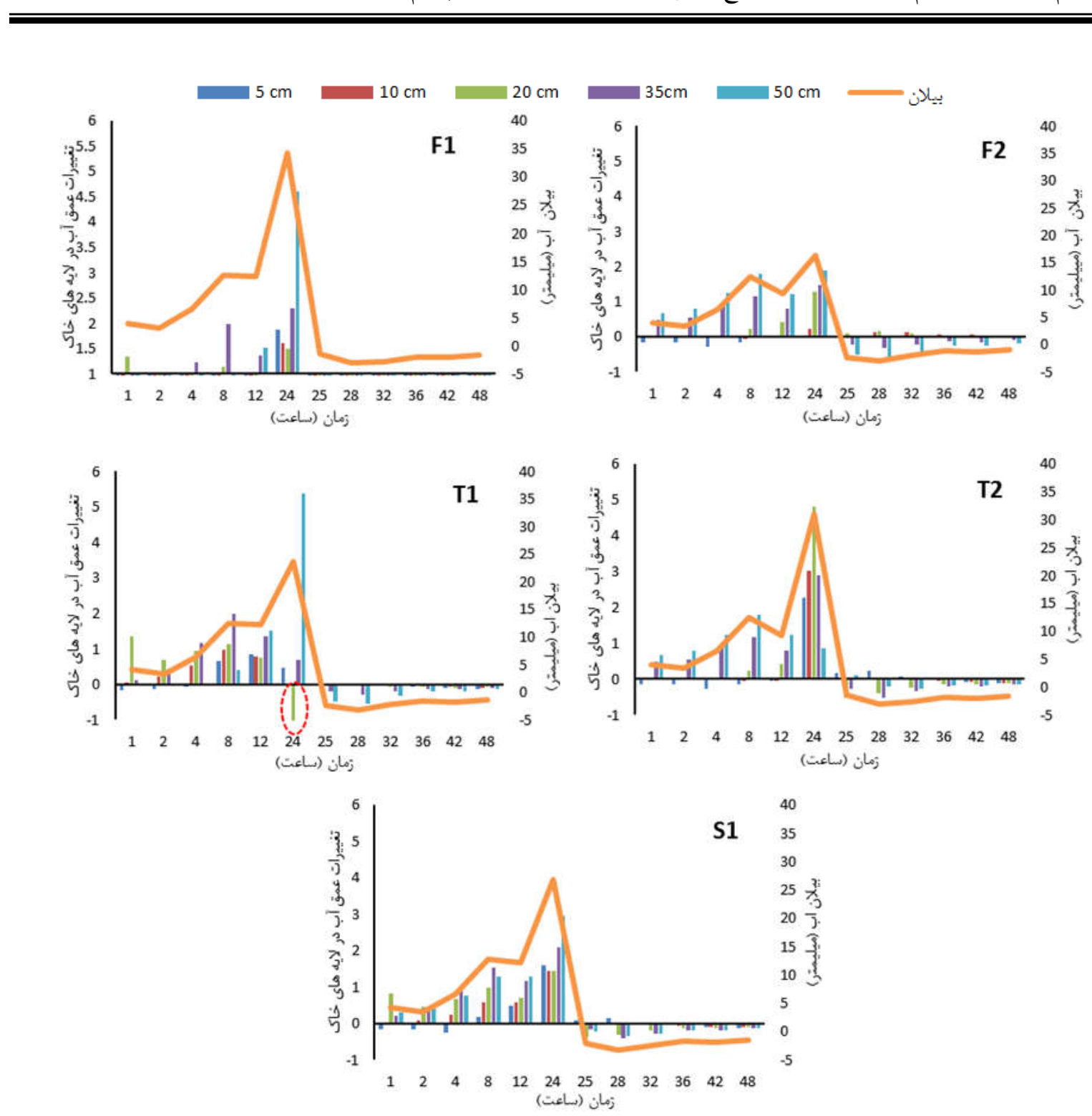

شكل ه. تغييرات عمق آب ذخيره شده و بيلان آب در زمانهاى مختلف براى بنج سناريو

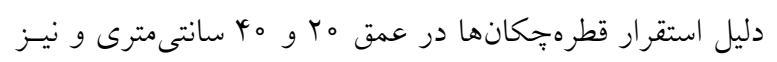

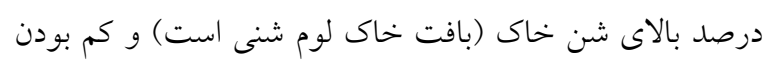

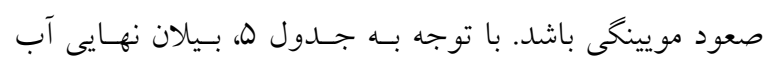

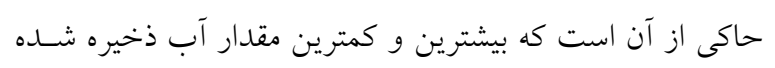

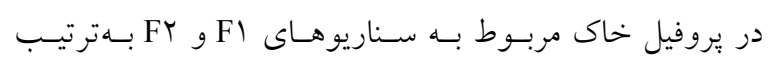

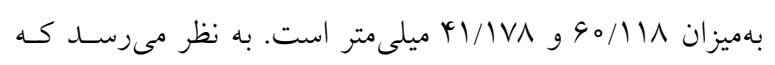

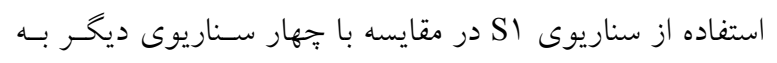

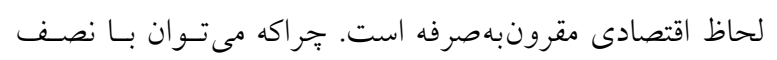

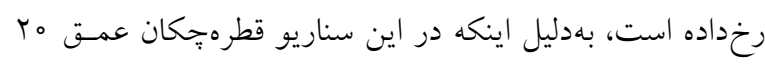

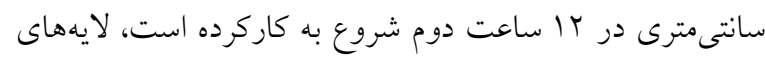

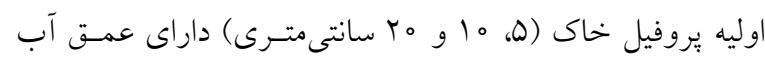

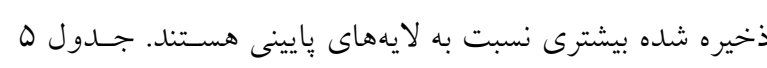

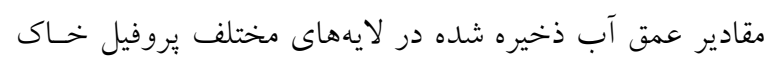

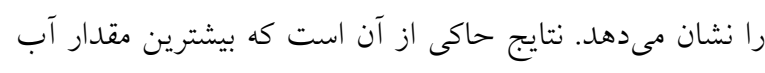

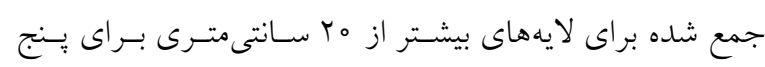

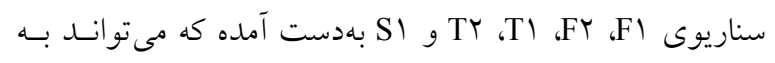


برآورد بيلان حجمى آب و الكوى رطوبتى آبيارى قطرهاى زيرسطحى در محيط متخلخل

\begin{tabular}{|c|c|c|c|c|c|}
\hline$S_{1}$ & Tr & $\mathrm{TI}$ & Fr & $\mathrm{F}_{1}$ & عمق لايه خاك (cm) \\
\hline $1 / 994$ & I/NTr & $1 / \pi \mu^{\prime}$ & $-0 / 9 Y \Lambda$ & $T / Q V$ & $\circ-\phi$ \\
\hline$r / 990$ & $T / V \circ Y$ & r/Tar & $\circ / \Delta \wedge A$ & $r / 4 v q$ & $0-10$ \\
\hline $\mathrm{r} / \mathrm{TTV}$ & r/rır & $r / \circ \circ \Delta$ & $1 / \Delta 0 \mathrm{~V}$ & $x \notin / 1$ & $10-10$ \\
\hline T/AKT & $r / 9 \circ r$ & r/Dro & $r / r \mu q$ & $r / 09$ & $10-Y_{0}$ \\
\hline F/MGY & t/ret & $r / 909$ & $r / 019$ & $r / 911$ & To-rQ \\
\hline$r / 9 T \Lambda$ & $Y / V Y Y$ & $\varphi / \pi)^{\prime}$ & r/9Y9 & D/Tar & $r \Delta-r_{0}$ \\
\hline$r / 949$ & $\Delta / \circ \Delta \varphi$ & $4 / 9 V 1$ & $\psi / I V Y$ & D/DrG & ro-r山 \\
\hline D/TrT & D/TKY & $4 / 990$ & r/994 & $0 / V / 9$ & $r \Delta-\varphi_{0}$ \\
\hline Q/Far & Q/DVG & Q/TYO & Q/०VQ & D/NOT & $Y \circ-1 Q$ \\
\hline $0 / 9 \pi /$ & D/VGY & D/4TA & $\Delta / \varphi_{\circ} \circ$ & $0 / 940$ & $\varphi \Delta-Q_{\circ}$ \\
\hline$\Delta / V G Y$ & $0 / 199$ & $\Delta / \Delta \vee \wedge$ & D/9r9 & $9 / 00 Y$ & $\Delta \circ-\Delta \Delta$ \\
\hline D/N & $0 / 999$ & $0 / 9 \Delta \Lambda$ & $\Delta / N F$ & $9 / 0 r_{9}$ & $\Delta \Delta-9 \circ$ \\
\hline OH/YAY & $\Delta Y / \pi \wedge \Delta$ & $\psi q / \Delta V^{4}$ & $4 Y / I V \Lambda$ & $90 / 111$ & بيالان آب (mm) \\
\hline
\end{tabular}

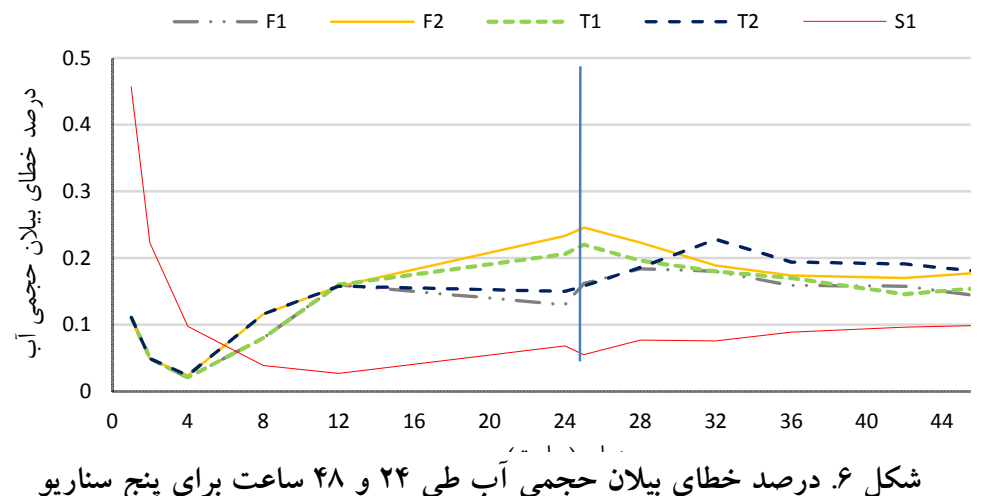

كردن ساعات كاركرد سيستم آبيارى قطرهاى در زمـان آبيـارى نتيجه گيرى

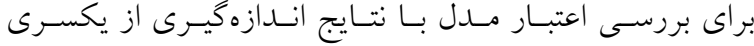

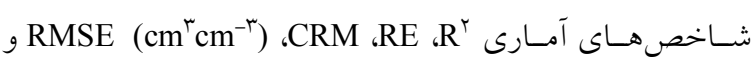
NRMSE

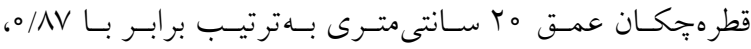

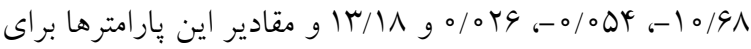

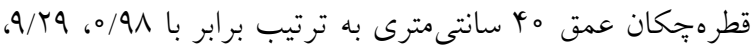

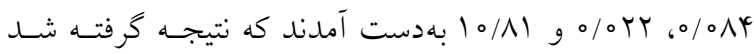
مدل HYDRUS 2D قادر است مقادير رطوبت حجمى خاك را با دقت بهتر و مناسبترى شبيهسازى كند.

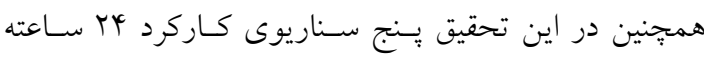

صرفهجويى كرد. شكل 9 درصد خطاى بيلان حجم براى سناريوهاى مختلف ترهن

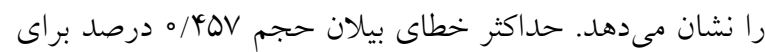

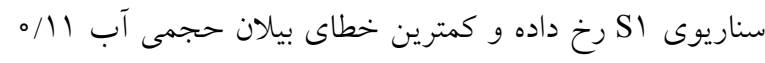

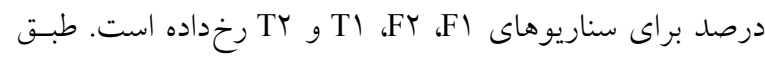
نظر دابرال و همكاران (11) براى حصول نتايج مطلوب، مقــدار اين خطا نبايد از يك درصد تجاوز كند. همجنين در اين تحقيق

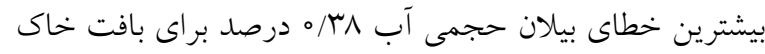

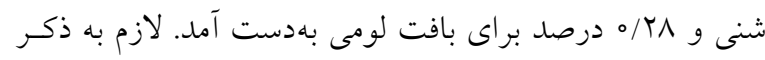

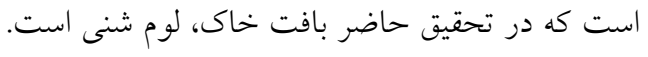


مختلف خـاك داراى مقــدار منفـى و در YY ســاعت اول داراى مقدار مثبتى است. بر اساس نتايج بهدست آمده، بيشترين مقـدار

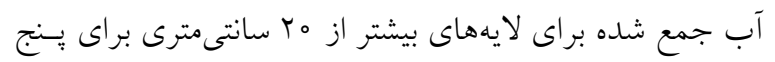

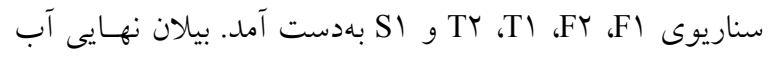
حاكى از آن است كه بيشترين و كمترين مقدار آب ذخيره شــده

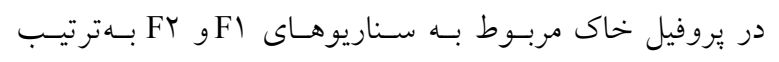

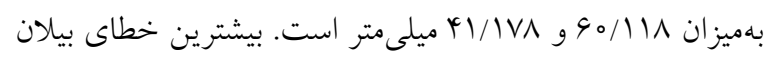
حجمى آب براى سناريوى IS (بافت خاك لوم شنى) بهدسـت

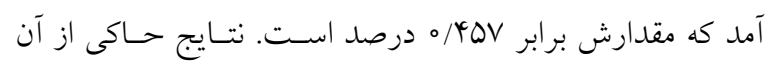
است كه استفاده از سناريوى SI در مقايسه با جِهــار سـناريوى ديخر به لحاظ اقتصادى مقرون بهصرفه است. جررا كه مسىتـوان با نصف كردن ساعات كاركرد سيستم آبيارى قطرهاى در زمـان آبيارى صرفهجويى كرد.

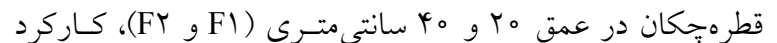

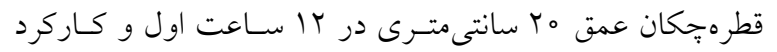

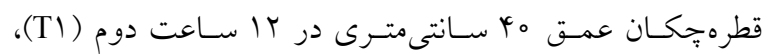

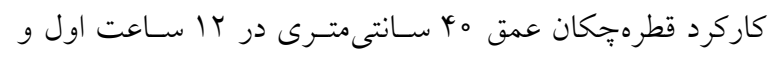

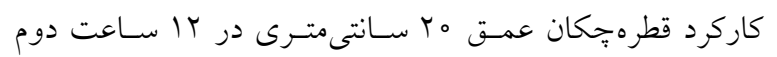

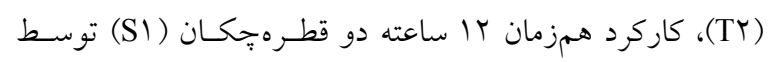
مدل HYDRUS 2D تعريف شدند. با توجه به نتـايج مـدل، در

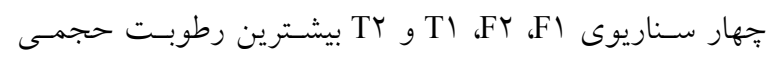
براى زمانهاى r I و ب r ساعت در فواصل ه و ه ا سانتىمتـرى عمودى، جاهايى كه قطرهجّانها قرار دارند بهدست آمــد و در

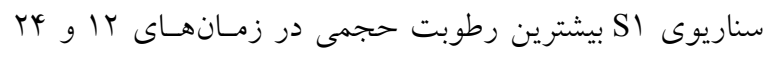

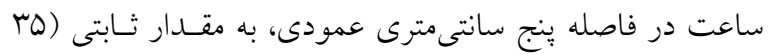

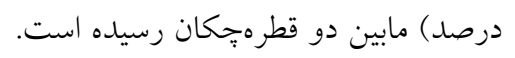

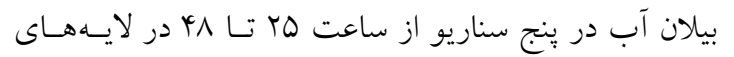

\section{منابع مورد استفاده}

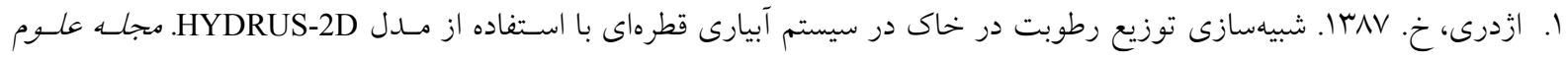

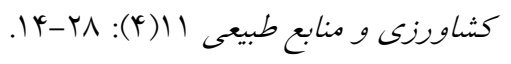

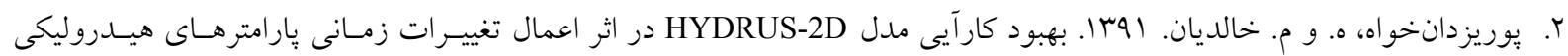

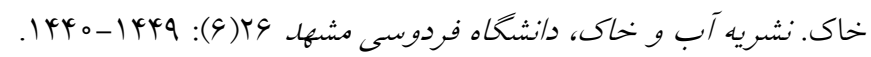

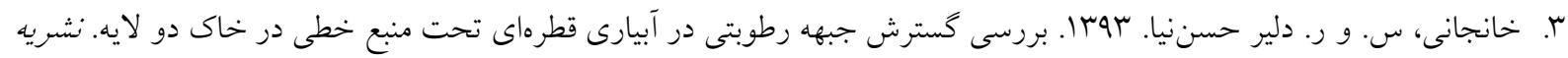

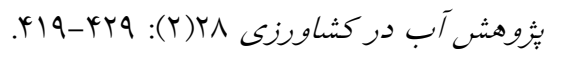

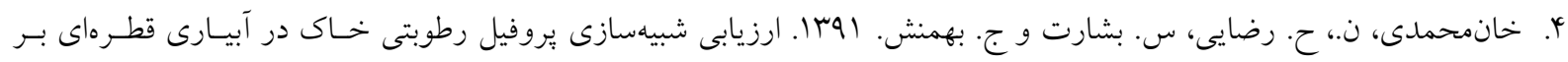

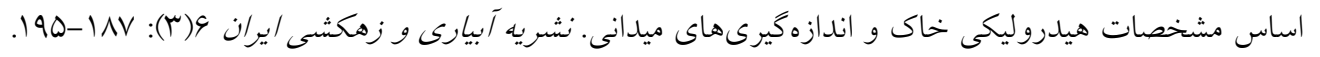

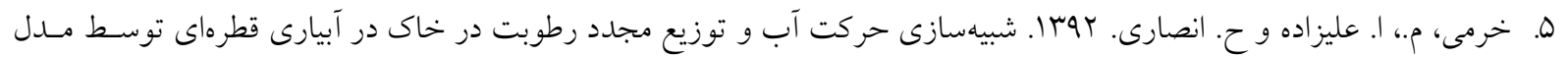

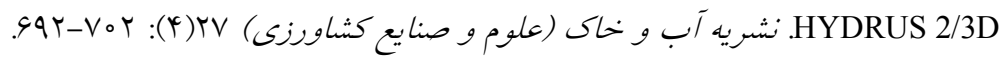

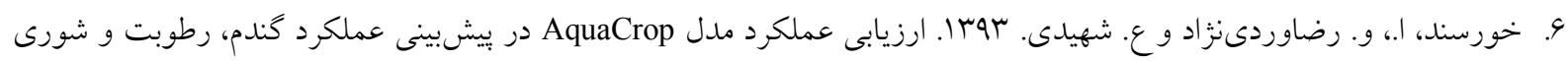

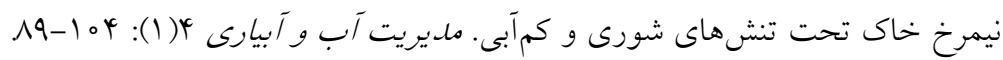

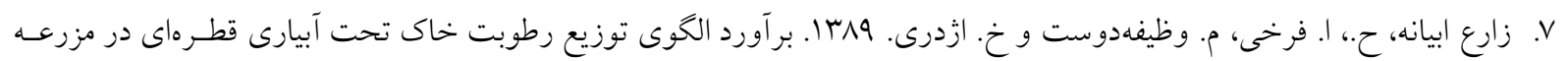

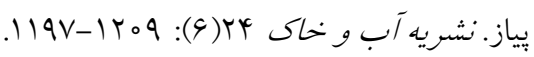

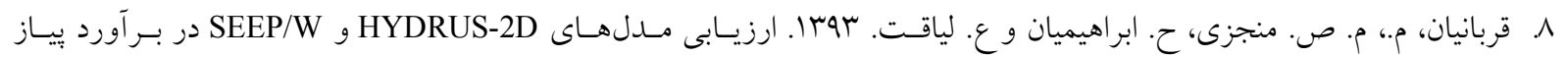

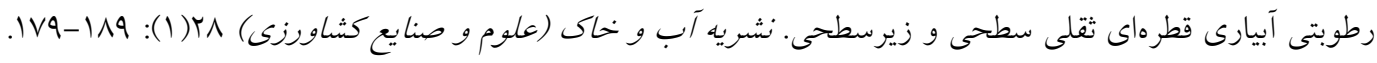




$$
\begin{aligned}
& \text { 9. نقوى، ه.، م. حسينى نيا، ش. كريمى گوغرى و م. ايراندوست. اجها. توانايى مدل HYDRUS 2D در شبيهسازى توزيع رطوبت در }
\end{aligned}
$$

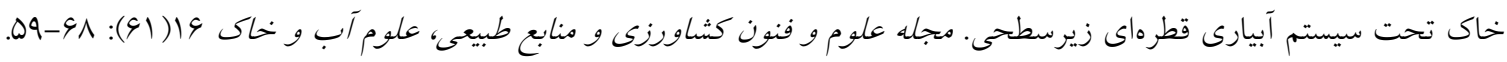

10. Cote, C. M., K. L. Bristow, P. B. Charlesworth, F. J. Cook and P. J. Thorburn. 2003. Analysis of soil wetting and solute transport in subsurface trickle irrigation. Irrigation Science 22: 143-156.

11. Dabral, P. P., P. K. Pandey, A. Pandey, K. P. Singh and M. S. Singh. 2012. Modelling of wetting pattern under trickle source in sandy soil of Nirjuli, Arunachal Pradesh (India). Irrigation Science 30(1): 287-292.

12. EL-Nesr, M. N., A. A. Alazba and J. Simunek. 2014. HYDRUS simulations of the effects of dual-drip subsurface irrigation and a physical barrier on water movement and solute transport in soils. Irrigation Science 32: 111-125

13. Jiusheng, L., J. Zhang and M. Rao. 2004. Wetting patterns and nitrogen distributions as affected by fertigation strategies from a surface point source. Agricultural Water Management 67: 89-104.

14. Kandelous, M. and J. Simunek. 2010a. Numerical simulations of water movement in a subsurface drip irrigation system under field and laboratory conditions using Hydrus-2D. Agricultural Water Management 97: 1080-1076.

15. Kandelous, M. and J. Simunek. 2010b. Comparison of numerical, analytical, and empirical models to estimate wetting patterns for surface and subsurface drip irrigation. Irrigation Science 28: 435-444.

16. Li, J., J. Zhang and M. Rao. 2004. Wetting patterns and nitrogen distribution as affected by fertigation strategies from a surface point source. Agricultural Water Management 67: 89- 104.

17. Mmolava, K. H. and D. Or. 2000. Root zone solute dynamics under drip irrigation: A review, Plant and Soil 222: 163-190.

18. Mostafazadeh-fard, B., H. Mansouri Mousavi and M. Feyzi. 2009. Effects of different levels of irrigation water salinity and leaching on yield and yield components of wheat in an arid region. Journal of Irrigation and Drainage Engineering 135(1): 32-38.

19. Patel, N. and T. B. S. Rajput. 2008. Dynamics and modeling of soil water under subsurface drip irrigated onion. Agricultural Water Management 95: 1335-1349.

20. Peter, J., J. Thorburn, F. Cook and K. L. Bristow. 2003. Soil-dependent wetting from trickle emitters: implications for system design and management. Irrigation Science 22: 121-127.

21. Roberts, T. L., S. A. White, A. W. Warrick and T. L. Thompson. 2008. Tape depth and germination method influence patterns of salt accumulation with subsurface drip irrigation. Agricultural Water Management 95: 669677.

22. Schaap, M. G. and F. J. Leij. 1998. Database related accuracy and uncertainty of pedotransfer functions. Soil Science 163: 765-779.Schaap, M. G., F. J. Leij and M. TH. Van Genuchten. 2001. ROSETTA: a computer program for estimating soil hydraulic properties with hierarchical pedotransfer functions. Journal of Hydrology 251: 163176.

23. Schmied, B., R. Schulin, U. Schmidhhalter and E. Frossard. 2001. Nitrogen Dynamicsand Leaching from HumusRich and Tile-Drained Agricultural Soil. Dissertation Submitted to the Swiss Federal Institute of Technology Zurich, for the Degree of Doctor of Natural Science. Swiss.Schwartzman, M. and B. Zur. 1986. Emitter spacing and geometry of wetted soil volume. Journal of Irrigation and Drainage Engineering 112(3): 242-253.Shan, Y., Q. Wang and CH. Wang. 2011. Simulated and measured soil wetting patterns for overlap zone under double points sources of drip irrigation. African Journal of Biotechnology 10(63): 13744-13755.

24. Simunek, J., M. TH. Van Genuchten and M. Sejna. 2006. The HYDRUS Software Package for Simulating Two- and Three-Dimensional Movement of Water, Heat, and Multiple Solutes in Variably- Saturated Media, Technical Manual, Version 1.0, PC Progress and Prague, Czech Republic.

25. Singh, D. K., T. B. S. Rajput, D. K. Singh, H. S. Sikarwar, R. N. Sahoo and T. Ahmad. 2006. Simulation of soil wetting pattern with subsurface drip irrigation from line source. Agricultural Water Management 83: 130-134.

26. Singh, A. K., R. Tripathy and U. K. Chopra. 2008. Evaluation of CERES Wheat and CropSyst models for waterNitrogen interactions in wheat crop. Agricultural Water Management 95: 776-786.

27. Siyal, A. A. and T. H. Skaggs. 2009. Measured and simulated soil wetting patterns under porous clay pipe subsurface irrigation. Agricultural Water Management 96: 893-904.

28. Skaggs, T. H., T. J. Trout, J. Simunek and P. J. Shouse. 2004. Comparison of HYDRUS-2D simulations of drip irrigation with experimental observations. Journal of Irrigation and Drainage Engineering 30: 304-310.

29. Van Genuchten, M. TH. 1978. Mass Transport in Saturated-Unsaturated Media: One-Dimensional Solutions, Research Rep. No. 78-WR-11, Water Resources Program, Princeton Univ., Princeton, NJ.

30. Van Genuchten, M. TH. 1987. A Numerical Model for Water and Solute Movement in and Below the Root Zone. Research Report No 121, U.S. Salinity Laboratory, USDA, ARS, Riverside, California. 


\title{
Estimation of Water Mass Balance and Soil Wetting Pattern for Subsurface Drip Irrigation in the Porous Media
}

\author{
A. Khorsand, M. Bazaneh, S. Besharat ${ }^{*}$ and K. Zeinalzadeh ${ }^{1}$
}

(Received: June 11-2016; Accepted: March 14-2018)

\begin{abstract}
Subsurface drip irrigation systems, compared to other irrigation systems (basin and furrow), enhance the delivery of water and nutrients directly into the root zone. The purposes of this study were to determine wetting front advancement in a subsurface drip irrigation and to compare the results with the HYDRUS 2D model simulation. In this study, the irrigation using T-Tape was carried out on a sandy-loam soil by two emitters at different irrigation times. The Wet moisture meter device was used to determine the soil water content. Evaluation of the simulated and measured soil water content was performed by using the adjusted determination coefficient $\left(\mathrm{R}^{2}\right)$, relative error (RE), and the normalized root mean square error (NRMSE). Based on the results, the NRMSE of soil water content prediction for the emitters at the depths of 20 and $40 \mathrm{~cm}$ was calculated to be in the range of 10 to 19 and 10 to 13 percent, respectively. Also, RE for the emitters at depths of 20 and $40 \mathrm{~cm}$ was in the range of -16 to -5 and 8 to 11 percent, respectively. The average $\mathrm{R}^{2}$ for the emitters at depths of 20 and $40 \mathrm{~cm}$ was calculated to be 0.87 and 0.98 , respectively. Also, five scenarios (F1, F2, T1, T2 and S1) were evaluated to assess the amount of water stored in the soil profile and water mass balance. The results indicated that the model could be used to predict the soil water content subsurface drip irrigation.
\end{abstract}

Keywords: HYDRUS Model, Rosetta Model, Scenario, Stored water, Water mass balance

1. Department of Water Engineering, Faculty of Agriculture, Urmia Lake Research Institute, Urmia University, Urmia, Iran.

*: Corresponding Author, Email: s.besharat@urmia.ac.ir 